INTERNATIONAL MONETARY FUND
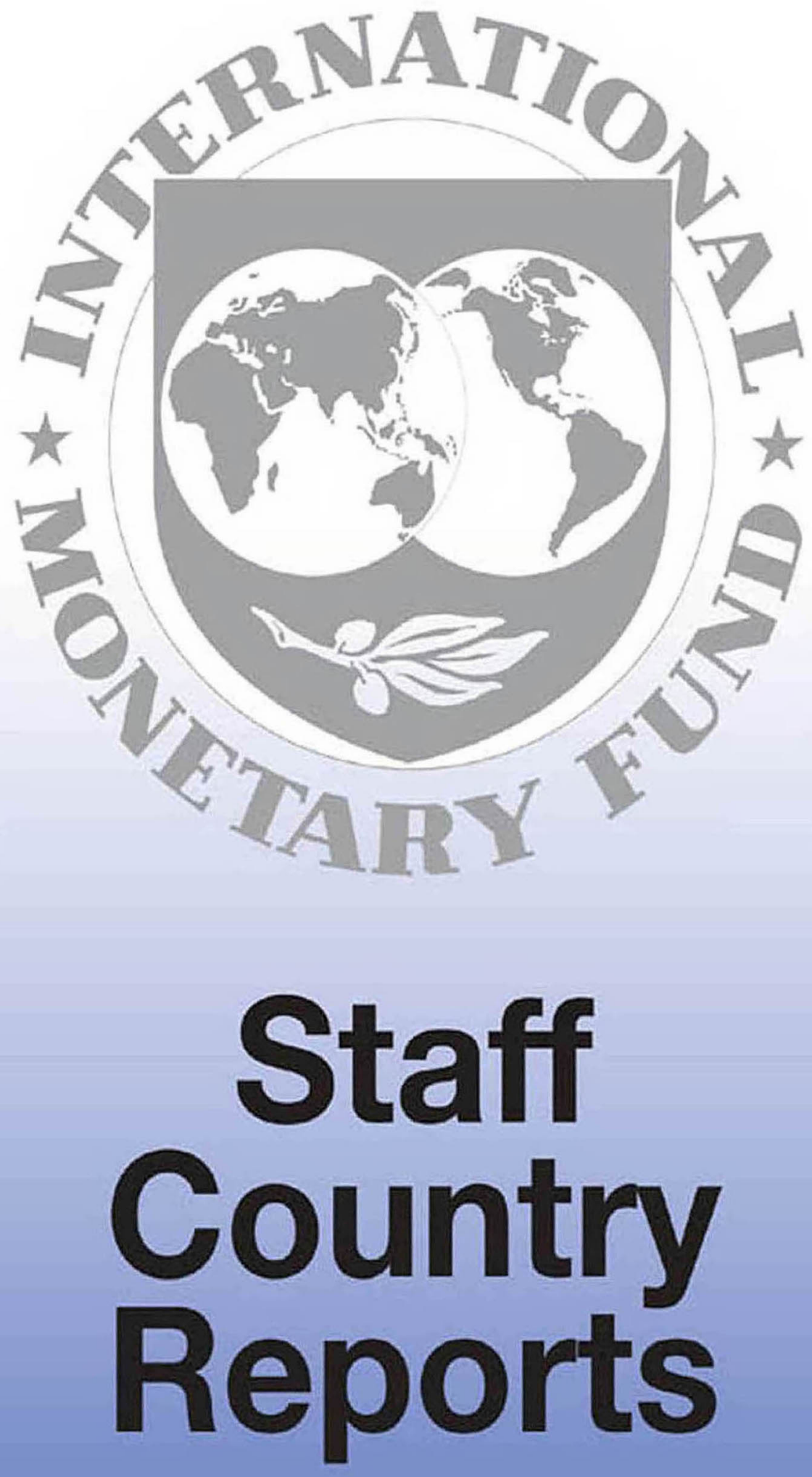


\section{Sri Lanka: Eighth and Final Review Under the Stand-By Arrangement-Staff Report; Press Release on the Executive Board Discussion; and Statement by the Executive Director for Sri Lanka.}

In the context of the Eighth Review under the Stand-By Arrangement, the following documents have been released and are included in this package:

- $\quad$ The staff report for the Eighth Review Under the Stand-By Arrangement, prepared by a staff team of the IMF, following discussions that ended on June 18, 2012, with the officials of Sri Lanka on economic developments and policies. Based on information available at the time of these discussions, the staff report was completed on July 6, 2012. The views expressed in the staff report are those of the staff team and do not necessarily reflect the views of the Executive Board of the IMF.

- $\quad$ A Press Release summarizing the views of the Executive Board as expressed during its July 20, 2012 discussion of the staff report that completed the request and/or review.

- $\quad$ A statement by the Executive Director for Sri Lanka.

The documents listed below have been or will be separately released.

Letter of Intent sent to the IMF by the authorities of Sri Lanka*

Technical Memorandum of Understanding*

*Also included in Staff Report

The policy of publication of staff reports and other documents allows for the deletion of market-sensitive information.

Copies of this report are available to the public from

International Monetary Fund • Publication Services

$70019^{\text {th }}$ Street, N.W. • Washington, D.C. 20431

Telephone: (202) 623-7430 • Telefax: (202) 623-7201

E-mail: publications@imf.org Internet: http://www.imf.org

\section{International Monetary Fund Washington, D.C.}


INTERNATIONAL MONETARY FUND

\section{SRI LANKA}

\section{Eighth Review Under the Stand-By Arrangement}

Prepared by the Asia and Pacific Department in Consultation with Other Departments Approved by Hoe Ee Khor and Taline Koranchelian

$$
\text { July 6, } 2012
$$

\section{Summary}

- $\quad$ Economic performance. Activity is moderating, the external current account deficit is narrowing, and official international reserves have stabilized. Headline inflation has moved up, but core inflation remains stable.

- Policies. Monetary conditions have tightened, credit growth is slowing, and the authorities are consolidating the shift to a flexible exchange rate regime. Easing activity and imports are adversely affecting revenues, and the interest bill is rising, but the authorities are committed to meeting their budget deficit target.

- $\quad$ Program performance. The end-June net international reserve target was met, and available data suggest that net domestic financing and reserve money met end-June indicative targets. All structural benchmarks have been implemented except for reform of the regulatory framework for private pension funds which, as anticipated, will not be passed before the program expires.

- Outlook and risks. Policy actions appear sufficient to deliver an adjustment in the external current account deficit needed to stabilize reserves with a relatively modest impact on growth and inflation. However, growth risks are on the downside as the economy is still vulnerable to external shocks, particularly if global conditions were to worsen sharply.

- Mission. A June 4-18 mission consisted of Messrs. Nelmes (Head), Anand, Mathai (Resident Representative), Tulin (all APD), and Ms. Khachatryan (SPR). Mr. Weerasinghe (OED) joined the discussions.

- $\quad$ Stand-By Arrangement: A 20-month Stand-By Arrangement in the amount of SDR 1.65 billion ( 400 percent of quota) was approved by the Executive Board on July 24, 2009, and extended at the second and third reviews and at the seventh review. The completion of the eighth and final review will enable a purchase of SDR 275.6 million. 


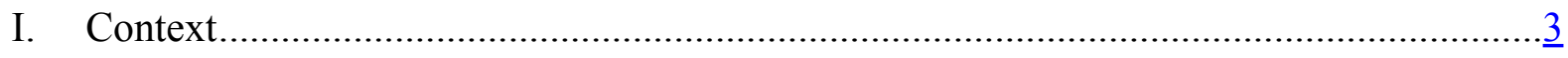

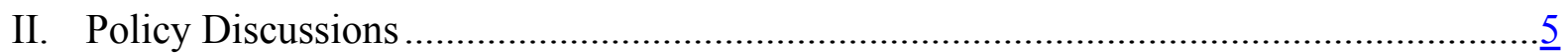

A. Monetary Policy, Exchange Rate, and Reserves ............................................... $\frac{5}{6}$

B. Fiscal Policy and State Enterprise Reform ............................................................

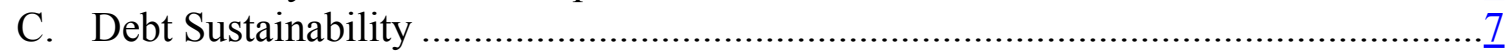

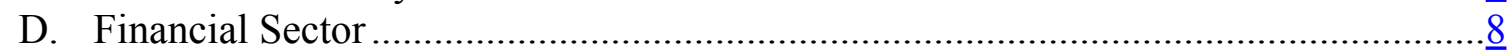

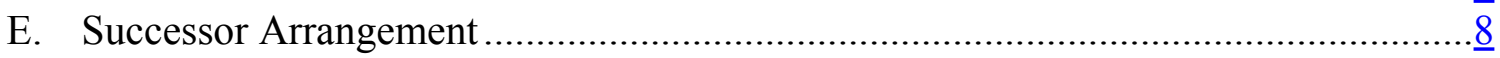

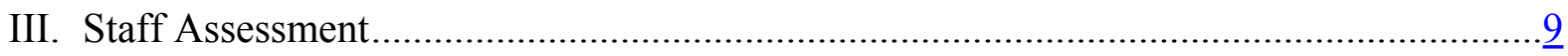

Figures

1. Economic and Program Performance ……............................................................

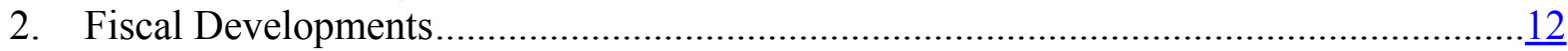

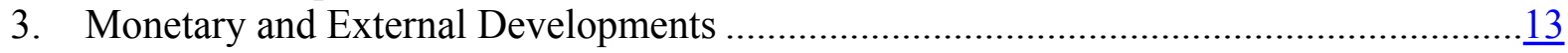

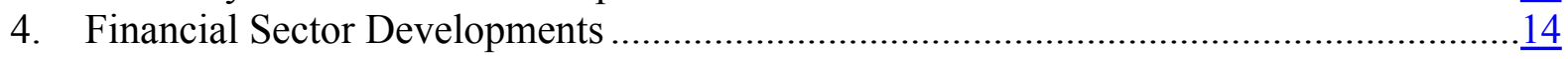

5. Public Debt Sustainability: Bound Tests ..............................................................

6. External Debt Sustainability: Bound Tests ...............................................................

Tables

1. Selected Economic Indicators, 2008-13

2. Summary of Central Government Operations, 2008-13

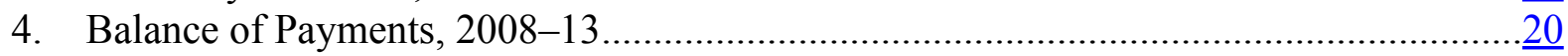

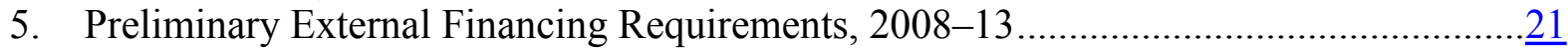

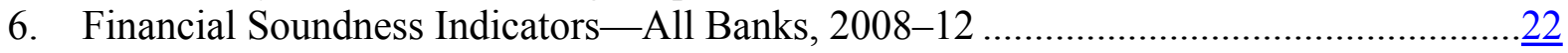

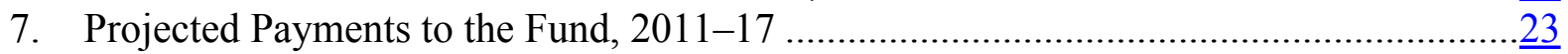

8. Reviews and Disbursements Under the Stand-By Arrangement......................................24

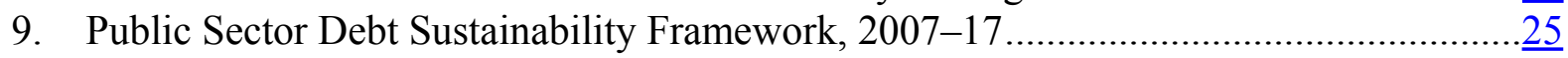

10. External Debt Sustainability Framework, 2007-17 ........................................................

Attachments

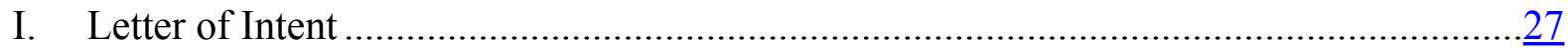

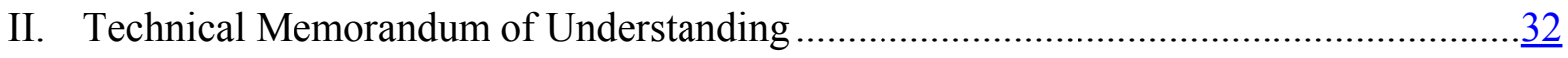




\section{Context}

1. Macroeconomic developments and outlook. Growth in the first quarter of 2012 remained robust, with real GDP expanding by 8 percent (y/y) supported by a rebound in agriculture and strong construction activity. However, growth has since begun to moderate in response to policy tightening and weakening global demand. Real GDP growth is now expected to slow to $63 / 4$ percent in 2012. Headline inflation rose to 7 percent in May following the increase in energy prices and exchange rate depreciation, but with core inflation stable around mid-single digits, headline inflation is expected to peak at just under 10 percent around end-2012. Both imports and exports recently contracted year-on-year in response to falling prices and weakening demand conditions - imports of consumption goods in particular have fallen, while investment goods imports continue to grow. With remittances and tourism holding up, the current account deficit is projected to narrow to about $5 \frac{1}{2}$ percent of GDP in 2012. The central bank's external reserves, which were falling sharply toward the end of 2011, have stabilized with gross international reserves at US\$5.8 billion (2.9 months of imports) at end-June.

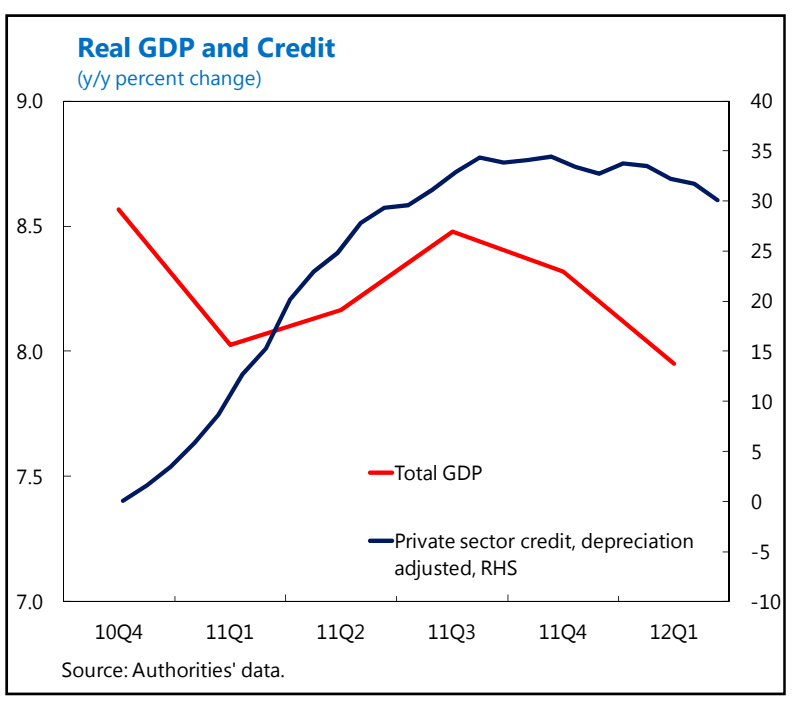

2. Monetary conditions. Interest rates increased further following the early-April policy rate hikes, as the Central Bank of Sri Lanka (CBSL) continued liquidity absorbing operations. Short-term prime lending rates are up about 100 basis points since the Seventh Review Board meeting, and rupee-denominated government bond yields have increased around 200 basis points. In response, and reflecting the tightening of credit policy, growth in credit to the private sector has begun to ease.
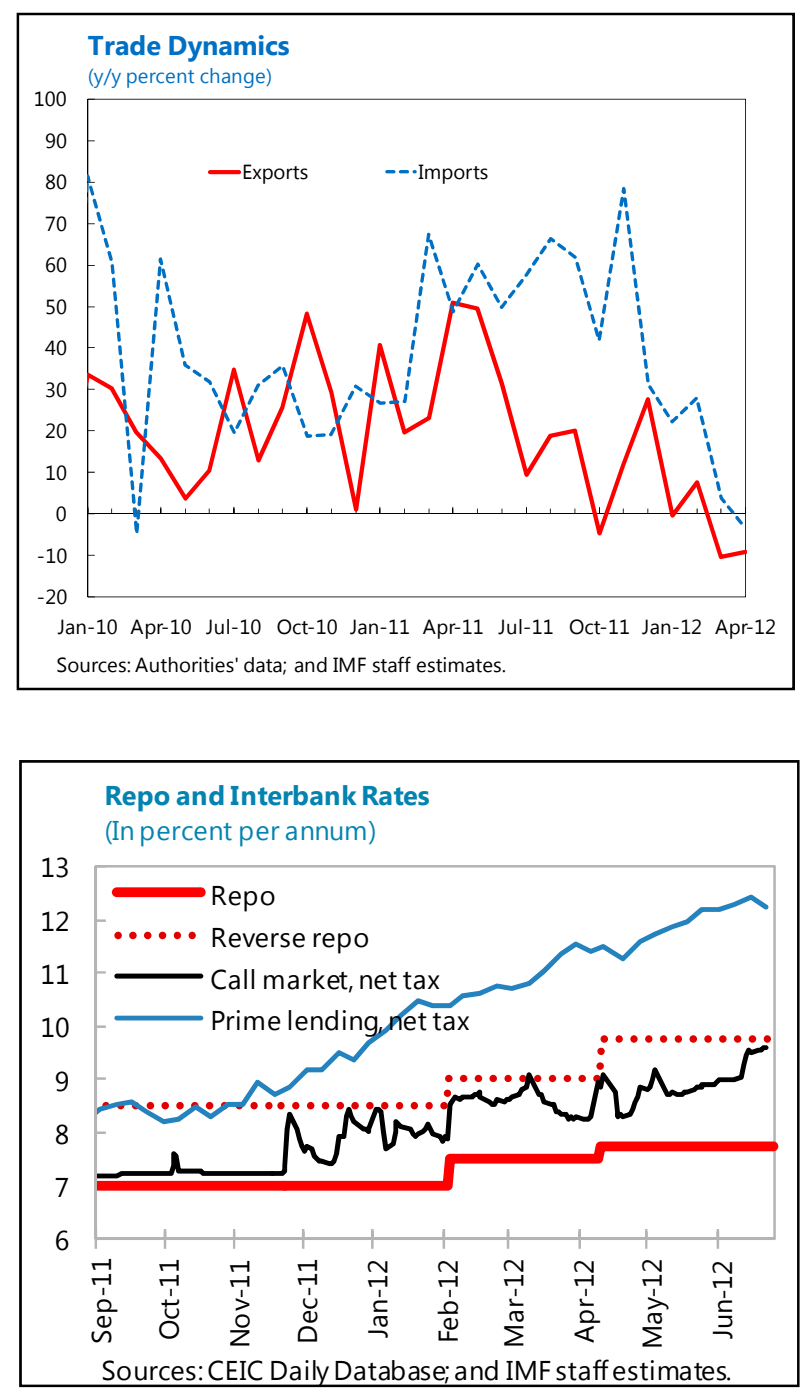
3. The exchange rate. The CBSL has largely ceased foreign exchange market intervention, allowing the rupee to move flexibly. However, volumes in the foreign exchange market have thinned with the slowing of external trade, enhanced supervision of foreign exchange trading, and the tightening of restrictions on banks' net open positions and forward transactions which the authorities had introduced to curb speculative positions they believed had generated heightened volatility. The market has become more settled recently.

4. The budget. Revenue growth has been adversely affected by declining imports and slowing activity, while base broadening and administration improvements have not gained traction as quickly as envisaged earlier. Interest costs are higher than budgeted owing to exchange-rate depreciation and higher domestic interest rates due to tighter monetary conditions, and external project financing disbursements have been slower than programmed. As a consequence, the budget deficit has been under pressure, and the authorities have responded by restraining noninterest current and domestically-financed capital expenditure.

5. State-owned enterprises (SOEs). Increases in fuel prices and electricity tariffs along with lower international oil prices are helping to reduce losses at the state-owned Ceylon Electricity Board (CEB) and Ceylon Petroleum Corporation (CPC). Some of this gain, however, is being offset by poor rainfall that has induced a shift in electricity generation from relatively cheap hydro to expensive thermal. On balance, the combined losses of the CEB and CPC are projected to fall to around one percent of GDP in 2012, from about $13 / 4$ percent last year.

6. Program targets. The end-June NIR performance criterion was met, in spite of unfavorable valuation changes on the reserve portfolio and an accelerated pay down of external oil-import credit lines. Available data indicate that reserve money and net domestic financing met end-June indicative targets. The Cabinet approved in April the amendment of the Petroleum Act, a structural benchmark. As discussed in the Seventh Review staff report, the regulatory framework for private sector pension funds will not be implemented before the program expires.

\section{Key risks include:}

- Deteriorating global environment. A sharper-than-anticipated slowdown in global demand, particularly in Europe and the United States-accounting for about 60 percent of Sri Lanka's exports - is a downside risk to growth and the external current account. Lower oil prices would provide some offset, while also benefitting the state-owned energy companies, however increased risk aversion could undermine capital inflows.

- Inflation. Though growth is slowing, there is not much slack in the economy, and there is a risk of second-round effects from pass through of depreciation and energy price increases. 
- $\quad$ Revenue. Weak imports associated with the external adjustment and slowing domestic demand pose challenges for achieving the budget's revenue targets. Meeting the deficit target through expenditure restraint could further dampen growth.

\section{Policy Discussions}

8. Policy adjustments have been successful in stabilizing a potentially serious deterioration in the balance of payments. Discussions for the Eighth Review focused on keeping macroeconomic stabilization policies on track, managing potential risks, and structural reforms needed to place the economy on a sounder footing.

\section{A. Monetary Policy, Exchange Rate, and Reserves}

9. Monetary policy. Staff agreed with the authorities that the current monetary- and credit-policy stance was appropriate. Tighter policy has helped to reduce credit growth and imports. While acknowledging the slowing of activity, staff also noted that credit growth had so far been constrained mainly by the ceiling imposed on banks, while demand for credit remained firm. Moreover, given little slack in the economy, the rise in headline inflation had potential for second round effects. The authorities agreed that monetary conditions should remain firm in

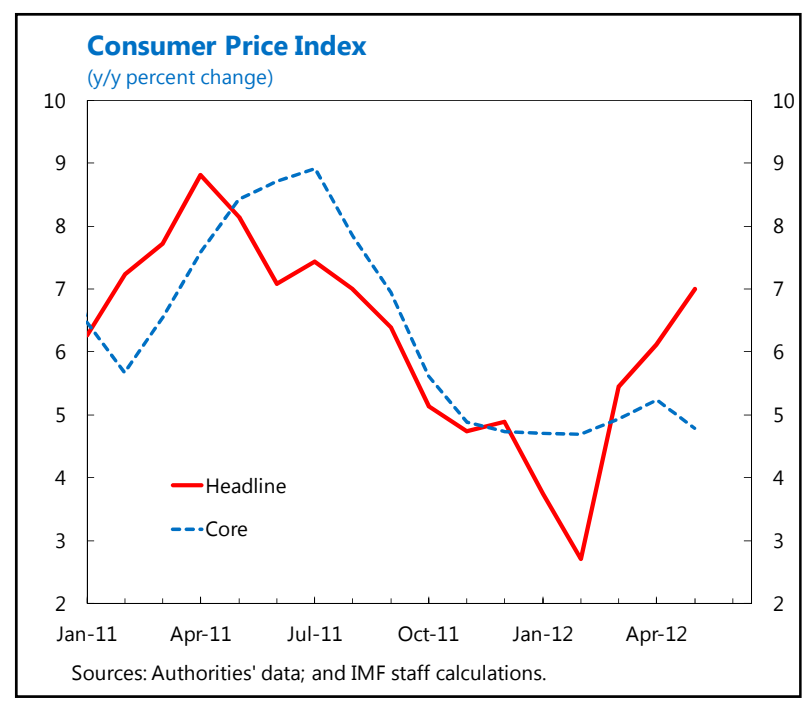
the near term until further evidence of an easing of demand and inflation pressures emerges. Looking forward, the authorities intend to phase out the credit ceiling, which staff supported. Staff encouraged the authorities to continue mopping up excess liquidity in the interim, to ensure a smooth transition.

\section{Exchange rate policy.}

Discussions focused on the challenge of developing a more liquid foreign exchange market, to help consolidate the shift to a flexible exchange rate regime. Staff noted that progressively rolling back restrictions on banks' net open and forward positions would help deepen the market and provide opportunities to hedge risks. As well, limited intervention could be considered to counter excessive

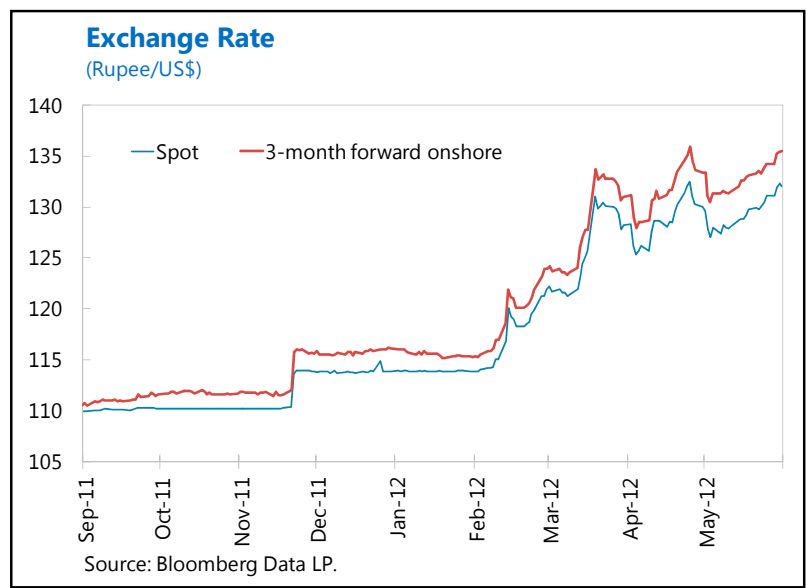


volatility, provided that it is not one-sided and not inconsistent with meeting the target on official reserves. The authorities had already relaxed the forward restriction for exporters, and noted that open limits were not precluding banks from financing external trade. They felt that these measures had been useful in curbing volatility that had the potential to unhinge expectations and weaken support for the new regime, and explained that further relaxation of the restrictions would be undertaken gradually. Staff also noted the potential benefit of increasingly emphasizing inflation control and macroeconomic stability rather than the exchange rate in communicating policy intentions.

\section{Balance of payments and}

reserves. With the external current account deficit narrowing, staff project the balance of payments to move to a small surplus in 2012, with net international reserves rising slightly. The authorities and staff agreed on the need to raise reserves to provide an additional buffer against external shocks, although the authorities were hopeful for a larger balance of payments surplus this year, supported by higher foreign direct investment inflows and current account

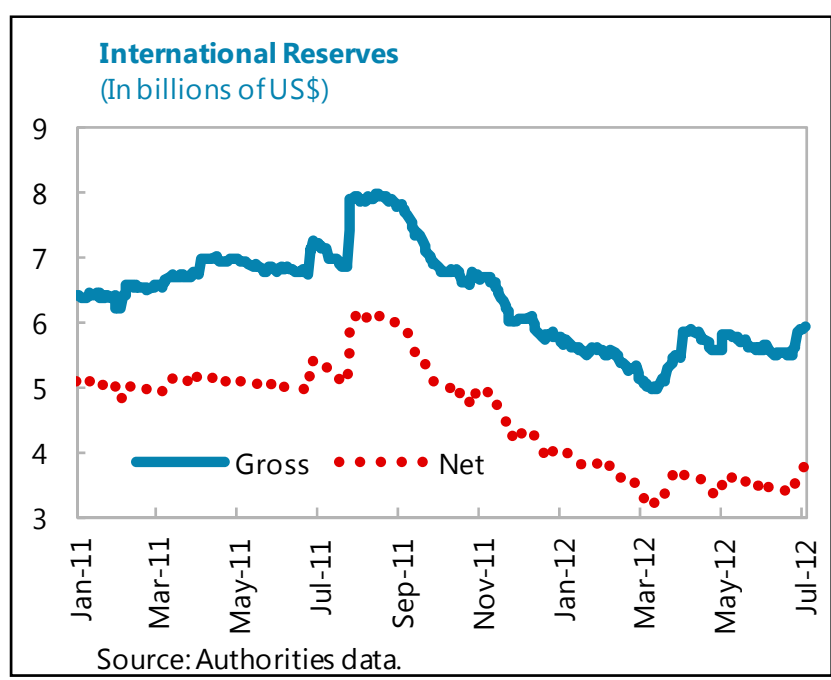
adjustment. Staff were more cautious, given the uncertain global environment, and the finding that while the real effective exchange rate has depreciated recently, standard methodologies suggest a mild overvaluation remains. ${ }^{1}$

\section{B. Fiscal Policy and State Enterprise Reform}

12. Revenues. Staff and the authorities agreed that revenue would likely fall short of the 2012 budget target by about $3 / 4$ percent of GDP. To address the situation, the authorities are redoubling efforts to improve revenue administration. In addition, the authorities recognize the need to improve the efficiency of the VAT, for which they have requested Fund technical assistance. Staff welcomed these measures, in particular broadening the VAT base, which is key to raising revenue.

\footnotetext{
${ }^{1}$ The macroeconomic balance and external sustainability approaches indicate overvaluation in the 6-9 percent range, though there is uncertainty over such estimates.
} 
13. The budget deficit. In addition to slowing revenue growth, the deficit is under pressure from rising interest expenses-likely to be about 0.3 percent of GDP higher than budgeted in 2012 - as a result of the depreciation and higher interest rates. Staff noted the importance of maintaining fiscal consolidation efforts to support the external current account adjustment and for debt sustainability. The authorities concurred, and while acknowledging the challenging fiscal environment, they emphasized their commitment to meet the program's end-June net domestic financing target, and the 2012 deficit objective of $6 \frac{1}{4}$ percent of GDP. They

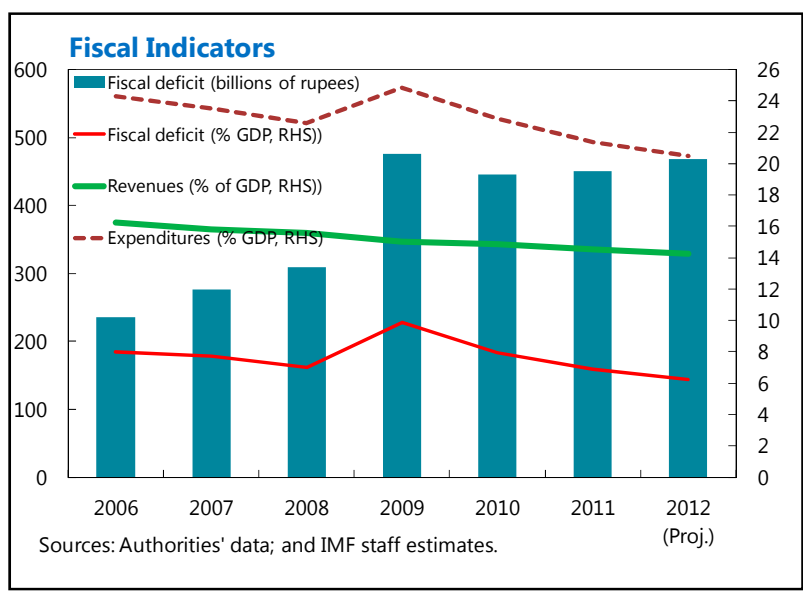
explained that tight control was being maintained over current spending, including on wages and security expenses, and domestically-financed capital expenditure would be reduced as needed. Staff welcomed these efforts, but agreed with the authorities that reducing capital spending was not desirable, given Sri Lanka's infrastructure development needs to support higher long-run potential growth.

14. State enterprise performance. While recent increases in domestic fuel and electricity prices are a step in the right direction, the authorities are mindful of the need for more fundamental reform to place the SOEs on a sustainable footing. A new $\mathrm{CEO}$ with international experience has recently been appointed to the $\mathrm{CPC}$, and consideration is once again being given to modernizing and expanding the oil refinery to shift the composition of imports away from costly refined products. Transmission losses have been reduced at the CEB, and a number of new generation plants are due to come on stream to change the electricity generation mix toward less costly sources.

\section{Debt Sustainability}

15. Debt dynamics are sustainable. Debt-to-GDP ratios shifted up in 2012 mainly as a consequence of the rupee depreciation. Notwithstanding, debt ratios are projected to decline over the baseline projection scenario, which incorporates conservative assumptions for growth, interest rates, and external financing needs.

- Public debt. As of end-2011, public debt is estimated at 78 $1 / 2$ percent of GDP, a little less than half of which is external public debt, with the rest being domestic. About one-fifth of domestic public debt comprises short-term treasury bills, the remainder includes medium- and long-term bonds and loans. Under the baseline scenario, in which the government brings the deficit down to 5 percent of GDP and reduces the primary deficit, the ratio of public debt to GDP falls from around 81 percent in 2012 to about $681 / 2$ percent by 2017 . This path is particularly vulnerable to significant 
exchange rate depreciation and contingent liabilities shocks - the standard bounds tests indicate the public debt-to-GDP ratio would be higher than baseline in 2017 by about 20 and 10 percentage points, respectively, for these shocks. Rollover risks appear manageable - the standard interest rate shock analysis indicates the public debt to GDP ratio would rise by about 7 percentage points relative to baseline by 2017 .

- $\quad$ External debt. As of end-2011, total external debt is estimated at $483 / 4$ percent of GDP, with external public debt at about 35 percent of GDP. Around three-quarters of total external public debt comprises project loans extended by multilateral and bilateral donors. The remaining one-quarter is contracted at market interest rates, of which half is short-term (nonresident investments in government securities) and half is medium-long term sovereign bonds. Under the baseline scenario, the external debt to GDP ratio is projected to fall from around 52 percent in 2012 to $42^{1} / 2$ percent in 2017. Rollover risks should be manageable, given the term structure and projected decline in the current account deficit, although the short-term external debt and amortization coverage of reserves is below 100 percent. The sensitivity analysis reveals that the greatest downside risks come from large depreciation and current account deficit shocks - the standard bounds tests indicate the external debt to GDP ratio would be higher than baseline in 2017 by about 20 and 11 percentage points, respectively, for these shocks.

\section{Financial Sector}

16. Financial system soundness. An FSAP update is assessing potential vulnerabilities in the financial sector. However, the authorities reported that slowing growth, as well as exchange rate depreciation and higher interest rates, have had only a marginal adverse impact on financial system soundness so far. Nonperforming loan ratios have increased slightly, and regulatory capital adequacy ratios have declined somewhat but remain well above the 10 percent minimum, while liquidity ratios have risen slightly. To enhance supervision, a new rating system has been introduced to incorporate qualitative and quantitative information, and statutory annual onsite inspections for all banks will begin in 2014.

\section{E. Successor Arrangement}

17. Successor arrangement. The authorities greatly appreciate the IMF's support under the expiring Stand-By Arrangement (SBA). They look forward to continued close engagement, and expressed interest in a successor arrangement to build on the achievements made under the SBA while providing support for their economic development and structural reform agenda. Staff concurred, and noted that IMF financial support would also provide a useful additional buffer for international reserves, given heightened global uncertainties. 


\section{STAFF ASSESSMENT}

18. Overview. Sri Lanka's economy is transitioning through a major macroeconomic policy adjustment in the context of a weakening global environment. Although an earlier adjustment would have reduced the loss of reserves, the authorities deserve to be commended for taking bold and decisive policy measures in recent months to arrest the reserve loss. The main challenges now are to build on these policy achievements while coping with an increasingly uncertain global outlook.

19. Monetary and exchange rate policy. The transition to a flexible exchange rate regime and winding down of foreign exchange market intervention has been a major achievement, and needs to be sustained. With a flexible exchange rate, the focus of monetary policy can shift increasingly to inflation control as a means for achieving broader macroeconomic stability, while allowing the exchange rate to act as a buffer for external shocks. In this context, the current monetary policy stance is appropriate, and a tightening bias should be maintained in the near term until further evidence of diminishing inflation pressures and credit demand emerge. Some two-way intervention to smooth exchange rate volatility is reasonable provided it does not adversely affect the target on reserve accumulation, while a gradual further relaxation of restrictions on banks' open and forward positions would help to deepen the foreign exchange market.

20. Balance of payments and reserves. Higher interest rates and the exchange rate depreciation have tightened and tilted the mix of monetary conditions consistent with delivering a needed adjustment in the external current account deficit. International reserves are projected to rise, though staff's baseline projection suggests their ratio to short-term debt would remain below 100 percent, and the level would be below $3 \frac{1}{2}$ months of prospective imports. Given the risks emanating from the global environment, staff encourages continued effort to build reserves while maintaining exchange rate flexibility.

21. Fiscal policy. The authorities' commitment to meet the 2012 budget deficit target is commendable, particularly given the weakening revenue and growth outlook and higher interest expenses. The target is achievable given the authorities' track record of prudent expenditure control. However, decisive improvements in revenue administration and base widening are needed to sustain fiscal consolidation while financing increased infrastructure investment, key for supporting robust growth over the longer run. In this context, staff welcomes the authorities' intention to strengthen VAT administration, and supports their request for IMF technical assistance.

22. State enterprise reform. Following the increase in retail energy prices and with international oil prices falling, losses at the SOEs should decline in 2012. The authorities are making efforts to place the energy companies on a sounder long-term financial footing, though results will take time. In the interim, it will be important to maintain a flexible pricing approach. 
23. Financial sector. Vigilance will be needed to monitor banks' financial soundness, given the significant expansion of credit in recent years, interest and exchange-rate shocks, and slowing economic activity. The FSAP update will provide an in-depth analysis of financial stability.

24. Review completion and successor arrangement. With quantitative performance criteria met, data suggesting indicative targets were met, and all but one benchmark implemented, staff supports the authorities' request for completion of the review. Staff believes that a successor arrangement would provide valuable support to the authorities in building reserves further, particularly with coverage relatively low and given the uncertain global environment, and in implementing their ongoing macroeconomic stabilization and structural reform agenda. Discussions on a successor arrangement are expected to take place during the fall 2012 Article IV consultation mission. 
Figure 1. Economic and Program Performance

Growth remained strong, but has slowed slightly in the recent quarters.

Growth

(In percent yoy)

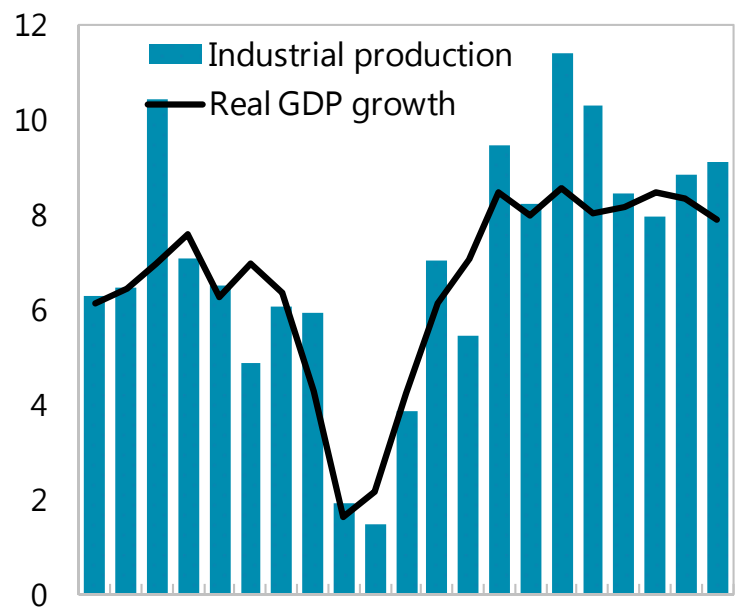

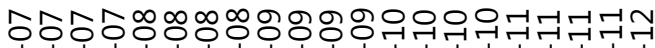

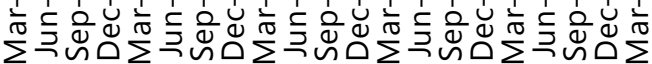

Import growth has slowed sharply...

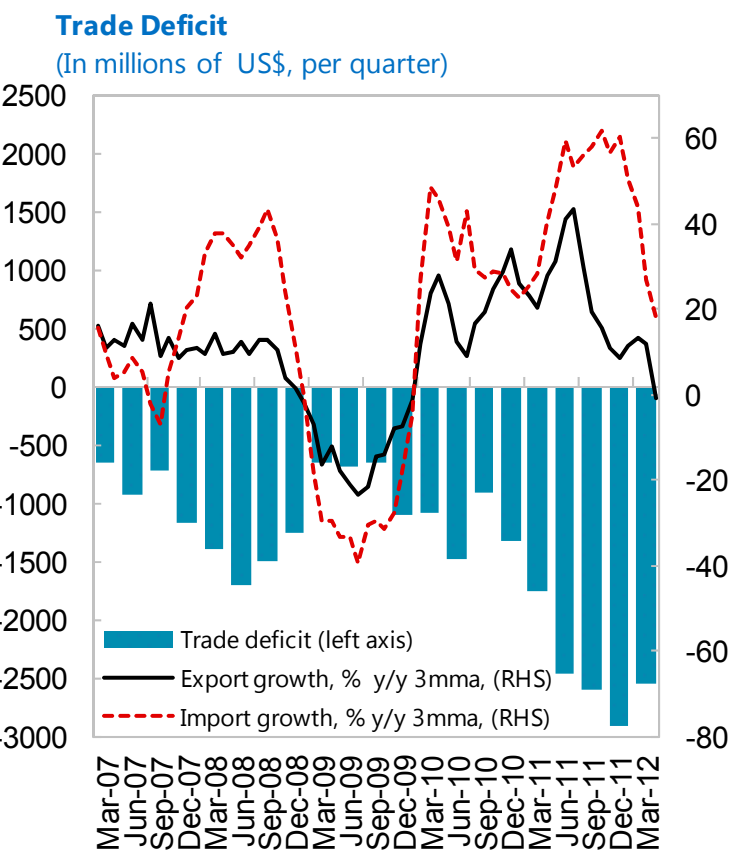

Headline inflation has risen in line with

administered fuel price increases and

depreciation, but core remains subdued.

Inflation

(In percent yoy)

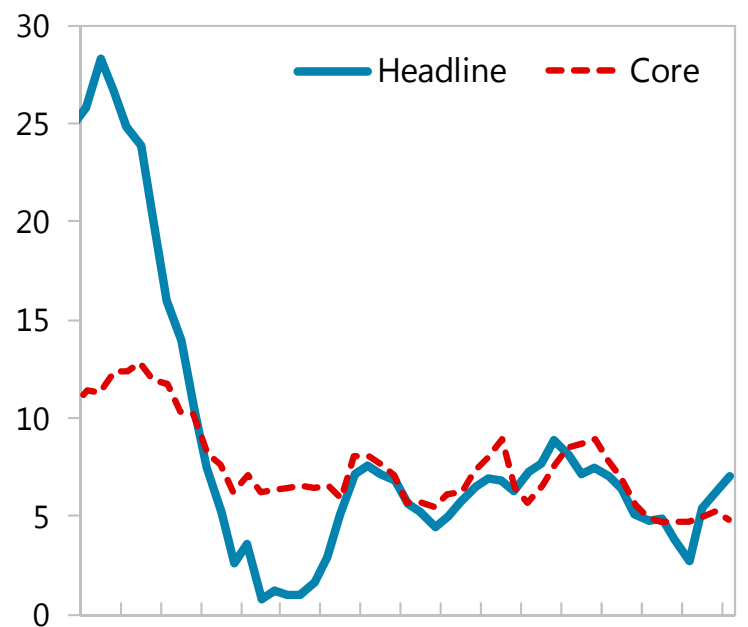

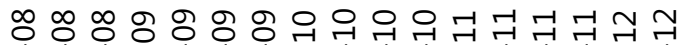

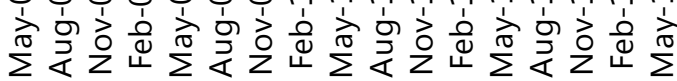

...reflecting tighter monetary conditions and exchange rate flexibility.

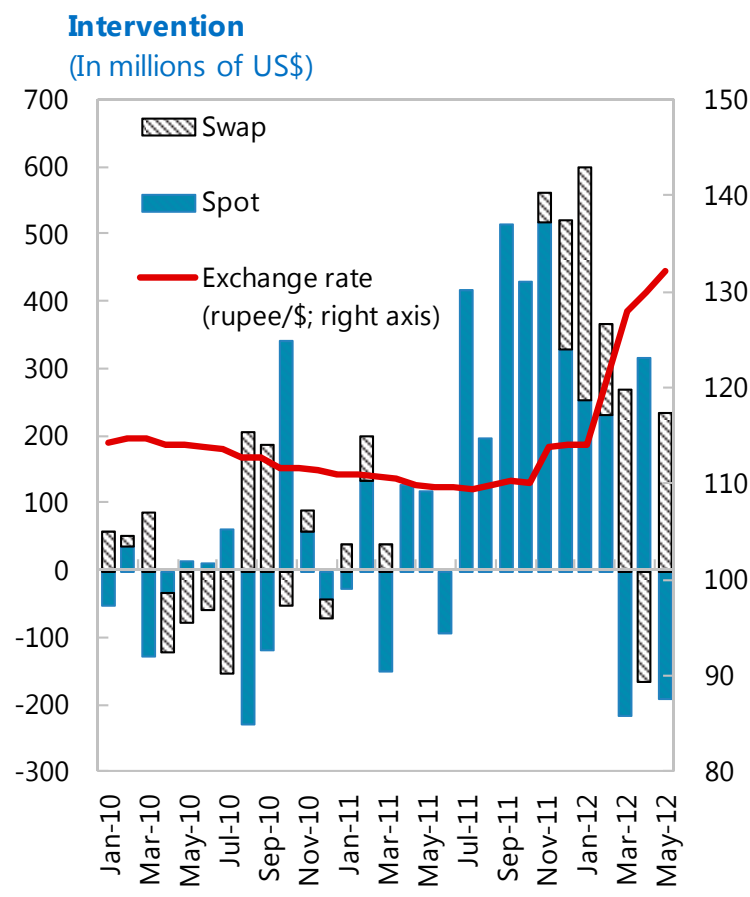

Sources: CEIC Data Company Ltd.; IMF, Information Notice System; and IMF staff estimates. 
Figure 2. Fiscal Developments

The fiscal deficit has fallen...

Fiscal Deficit

(In billions of rupees)

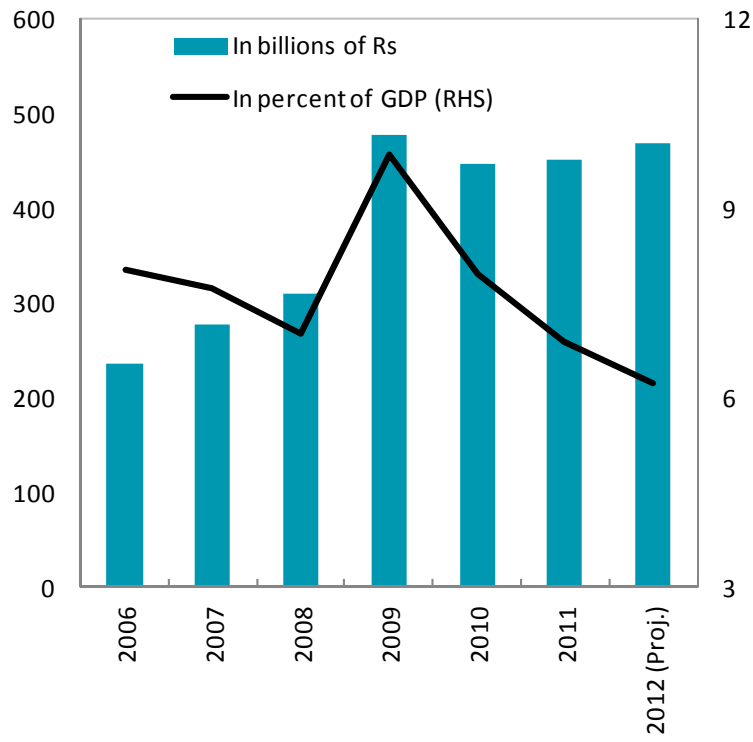

Because of tight control over primary expenditures...

\section{Government Expenditure}

(In percent of GDP)

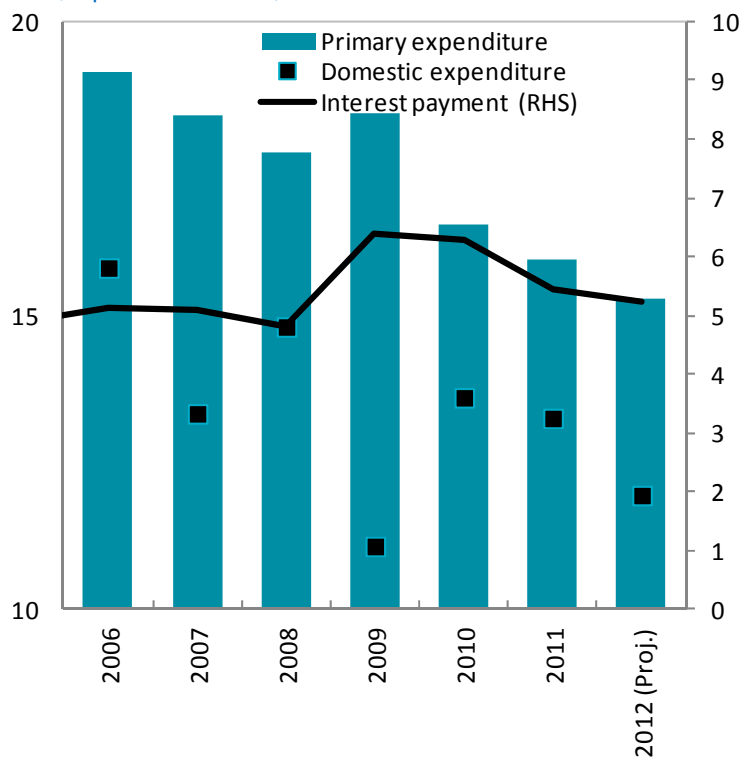

... despite declining revenues.

Government Revenues

(In billions of rupees)

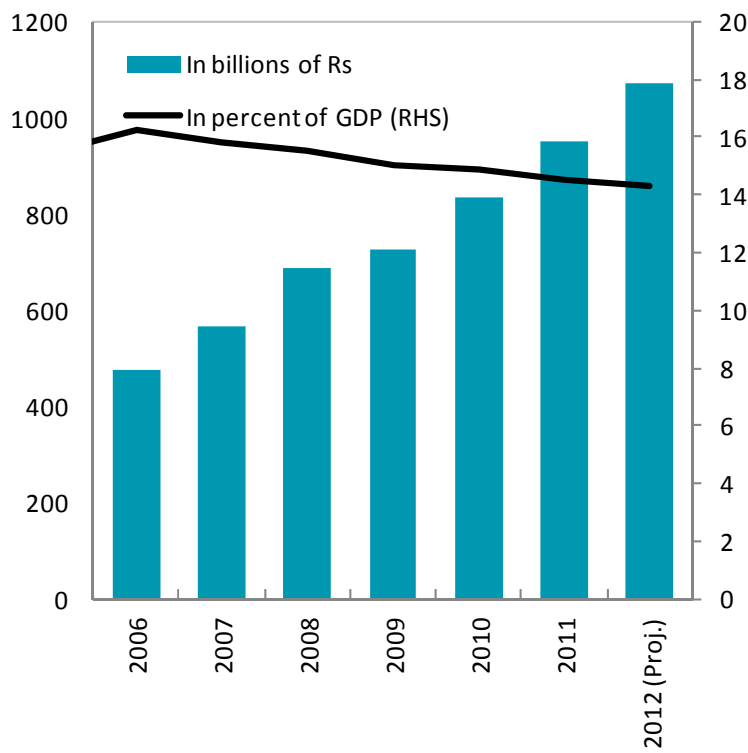

... government debt has declined.

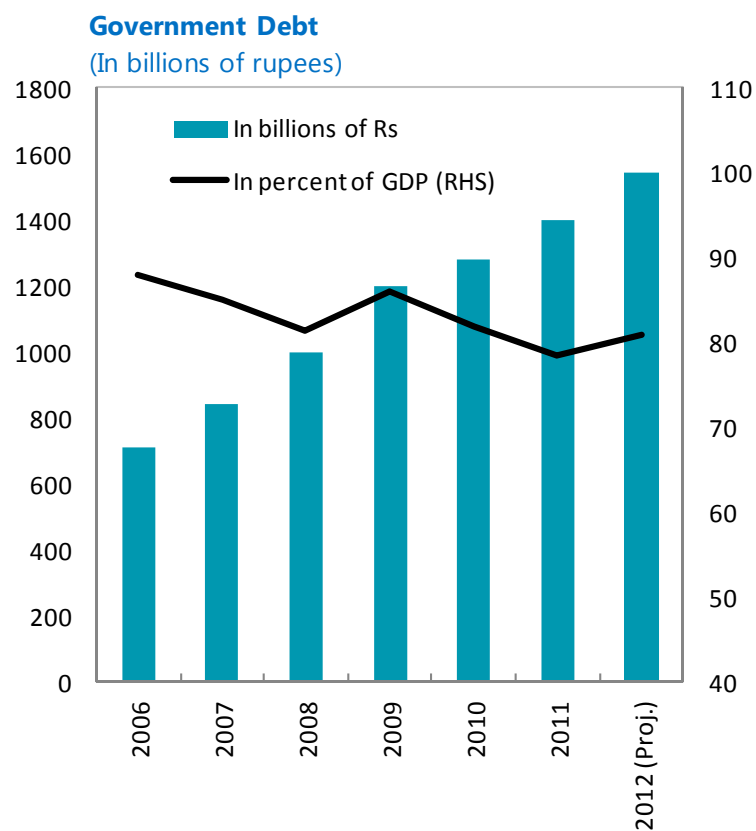

Sources: Central Bank of Sri Lanka; CEIC Data Company Ltd.; Bloomberg LP; and IMF staff estimates. 


\section{Figure 3. Monetary and External Developments}

Monetary conditions have tightened.

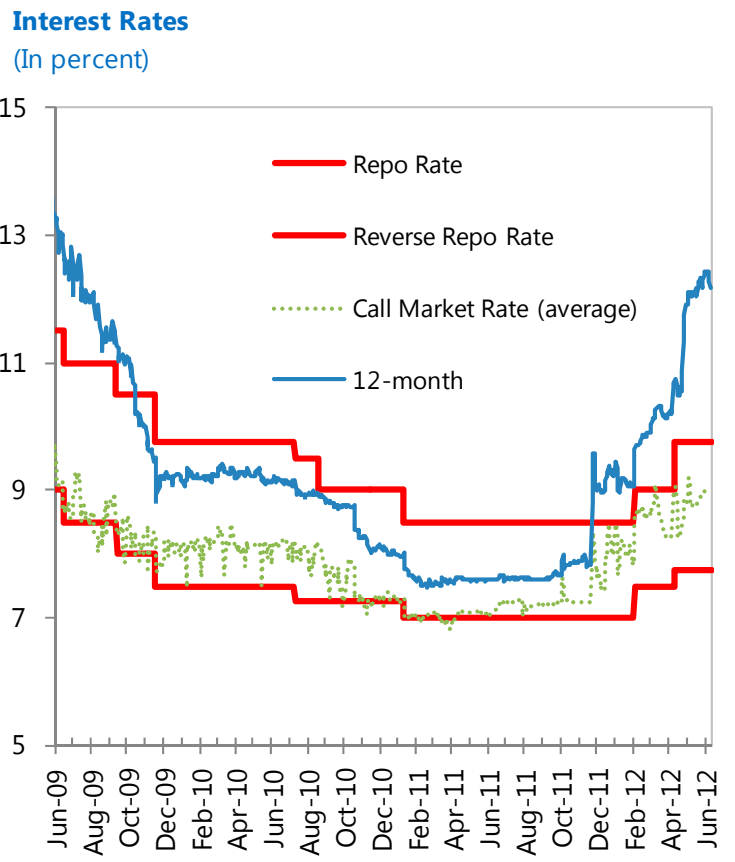

External reserves have stabilized after declining in 2011.

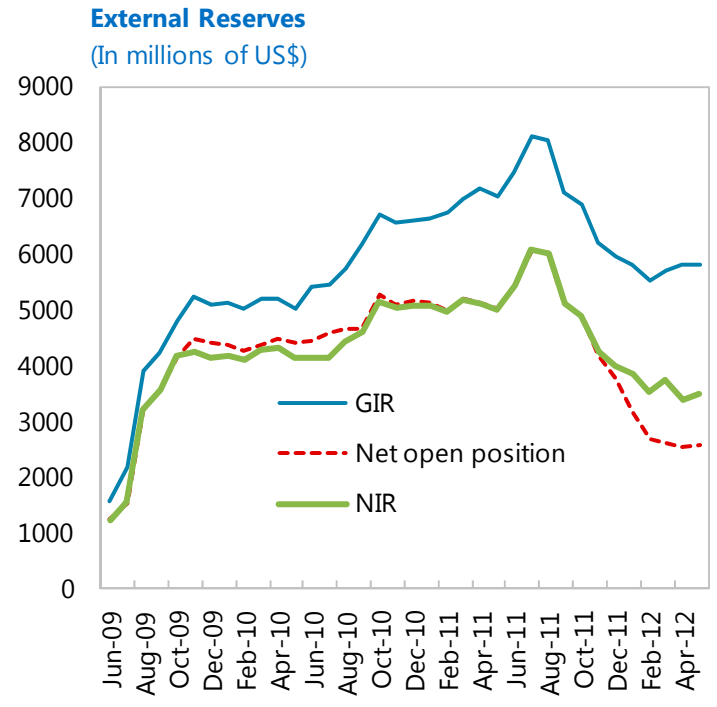

And credit growth has slowed, also reflecting the introduction of a credit ceiling.

Credit Growth and Excess Liquidity

(In percent)

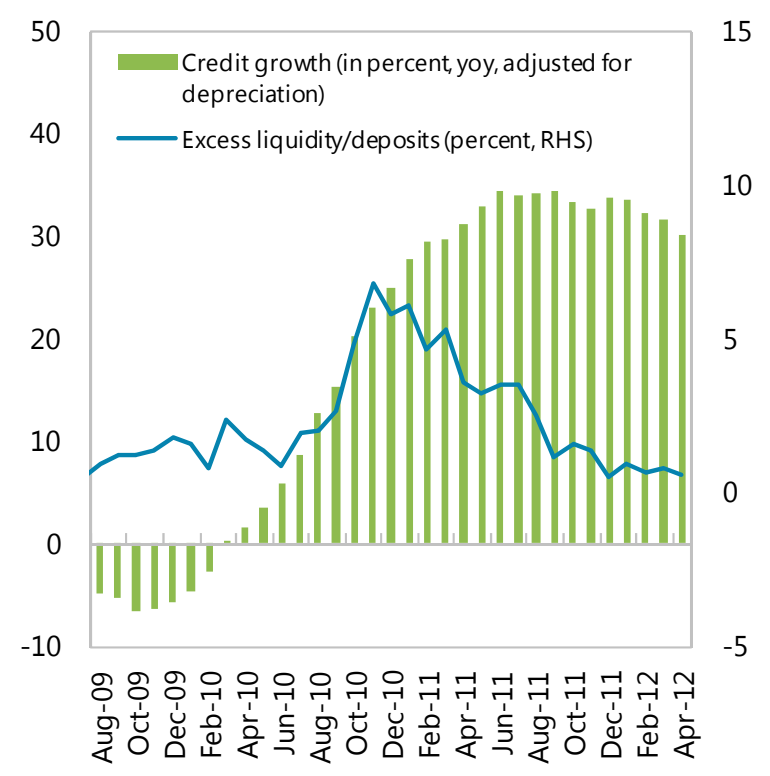

The real exchange rate has depreciated sharply.

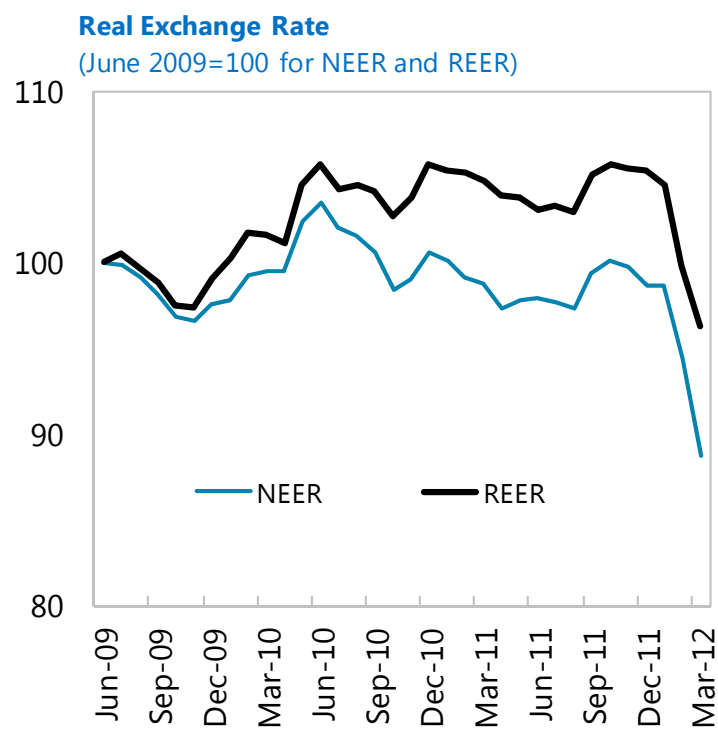

Sources: Central Bank of Sri Lanka; CEIC Data Company Ltd.; Bloomberg LP; and IMF staff estimates. 
Figure 4. Financial Sector Developments

The stock market has declined and foreign interest remained modest.

Stock Market

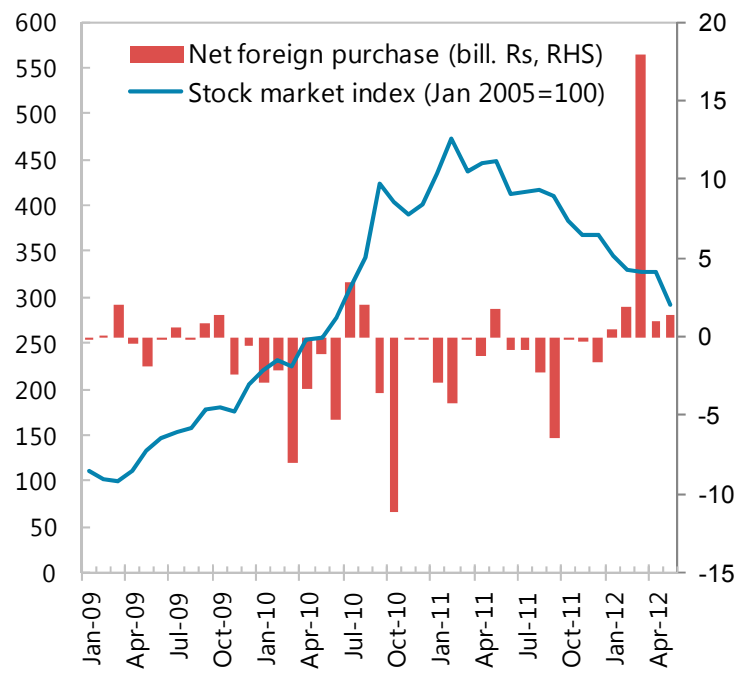

Sri Lanka's sovereign risk spreads are above Emerging Asia.

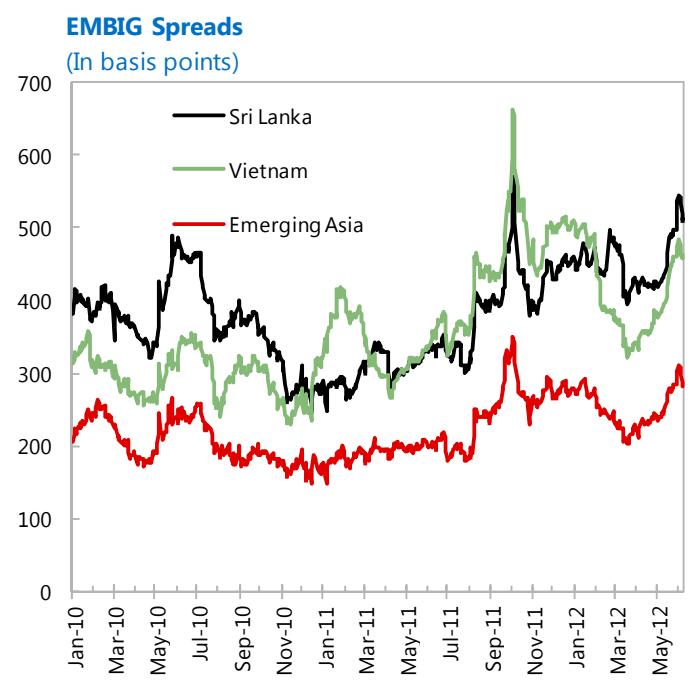

The Price Earnings Ratio has declined to around the average for the region.

Price Earning Ratios

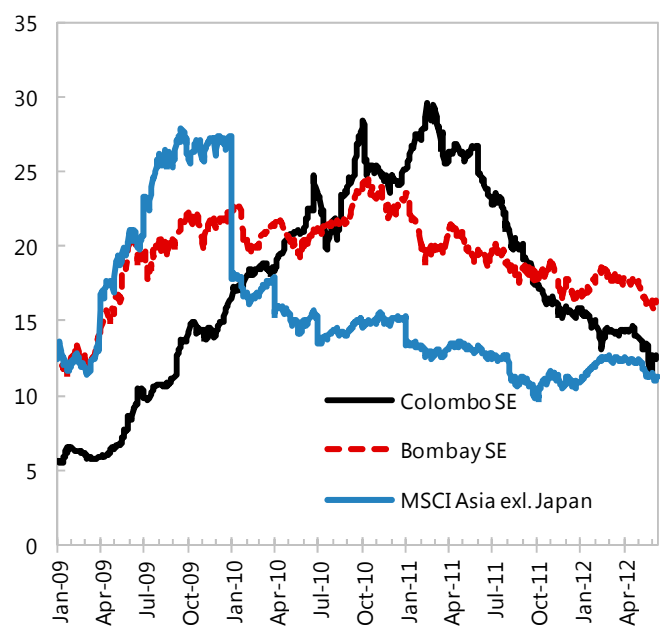

The NPLs of the banking system remain low, but edged up slightly more recently.
NPL and CAR
(In percent)

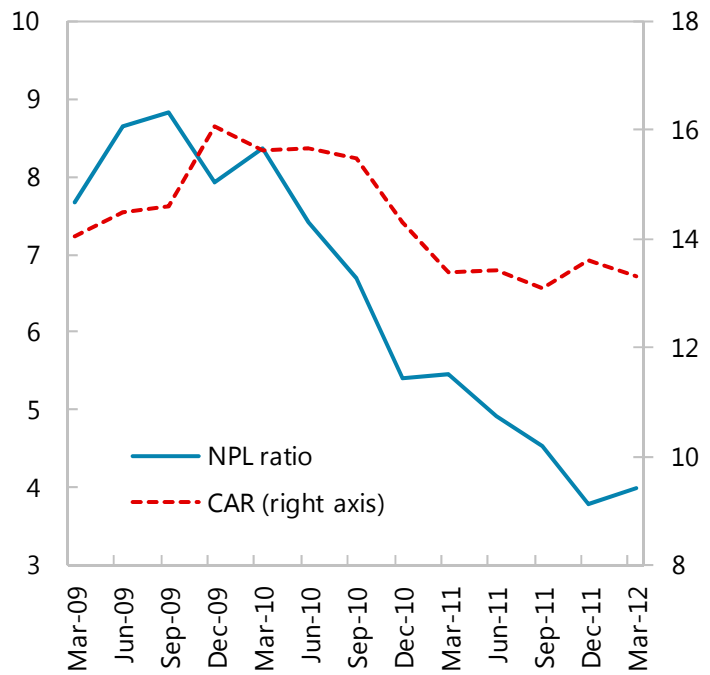

Sources: Central Bank of Sri Lanka; CEIC Data Company Ltd.; Bloomberg LP; and IMF staff estimates. 
Figure 5. Public Debt Sustainability: Bound Tests 1/ 2/

(Public debt in percent of GDP)

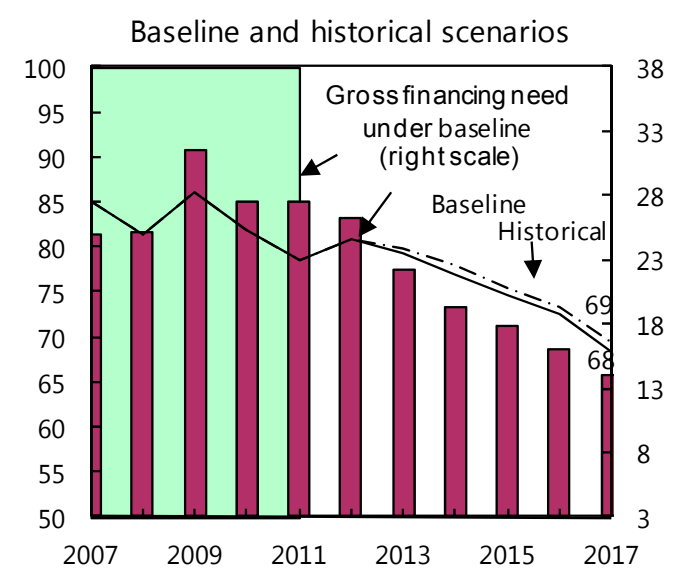

Growth shock (in percent per year)

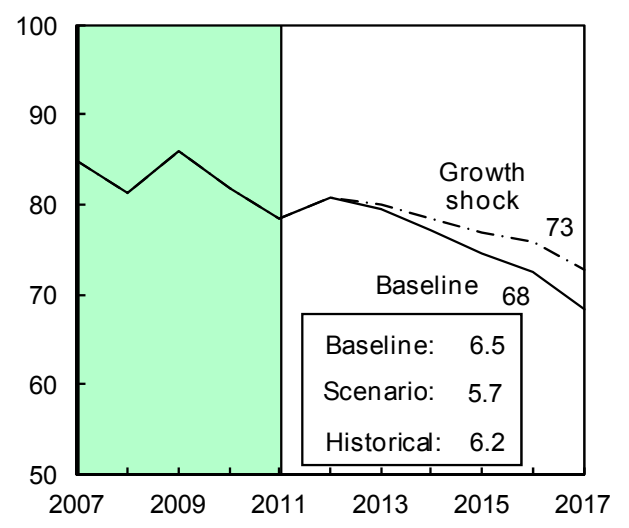

Combined shock $3 /$

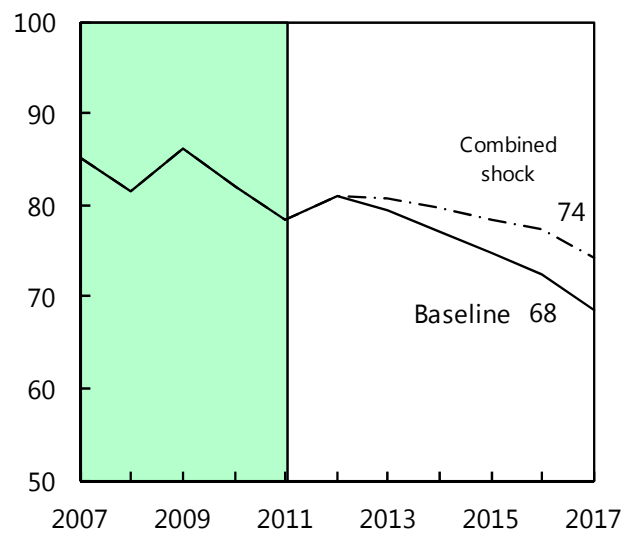

Interest rate shock (in percent)

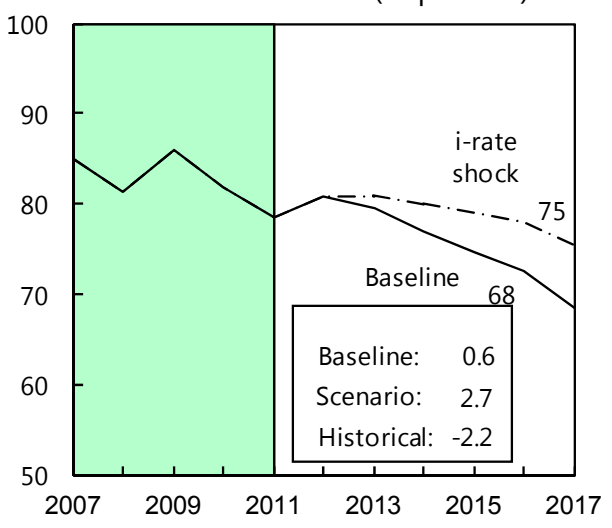

Primary balance shock (in percent of GDP) and no policy change scenario (constant

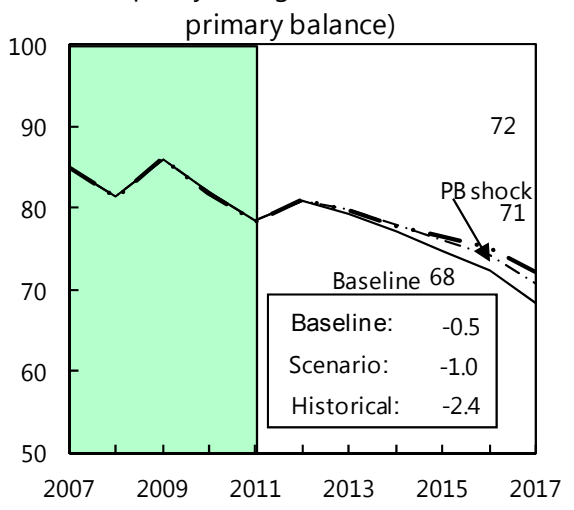

Real depreciation and contingent liabilities shocks 4/

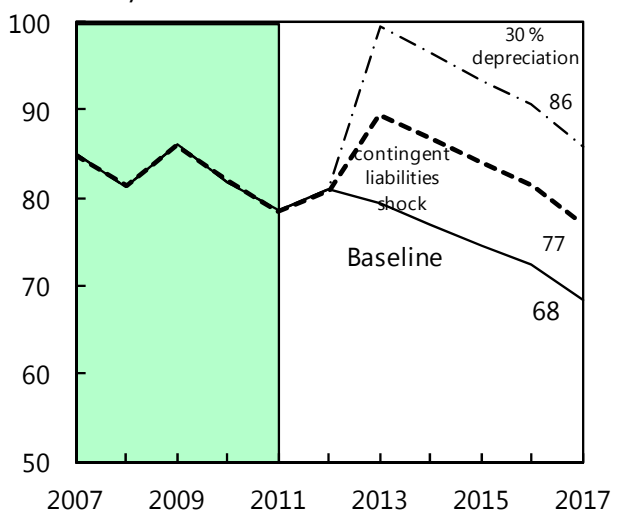

Sources: International Monetary Fund, country desk data, and staff estimates.

$1 /$ Shaded areas represent actual data. Individual shocks are permanent one-half standard deviation shocks. Figures in the boxes represent average projections for the respective variables in the baseline and scenario being presented. Ten-year historical average for the variable is also shown.

2/ For historical scenarios, the historical averages are calculated over the 10-year period, and the information is used to project debt dynamics five years ahead.

3/ Permanent 1/4 standard deviation shocks applied to real interest rate, growth rate, and primary balance.

4/ One-time real depreciation of 30 percent and 10 percent of GDP shock to contingent liabilities occur in 2013, with real depreciation defined as nominal depreciation (measured by percentage fall in dollar value of local currency) minus domestic inflation (based on GDP deflator). 
Figure 6. Sri Lanka: External Debt Sustainability: Bound Tests 1/ 2/ (External debt in percent of GDP)

Baseline and historical scenarios

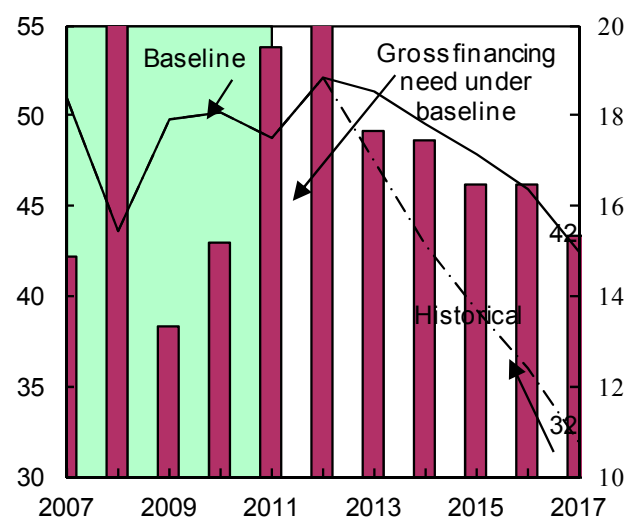

Growth shock (in percent per year)

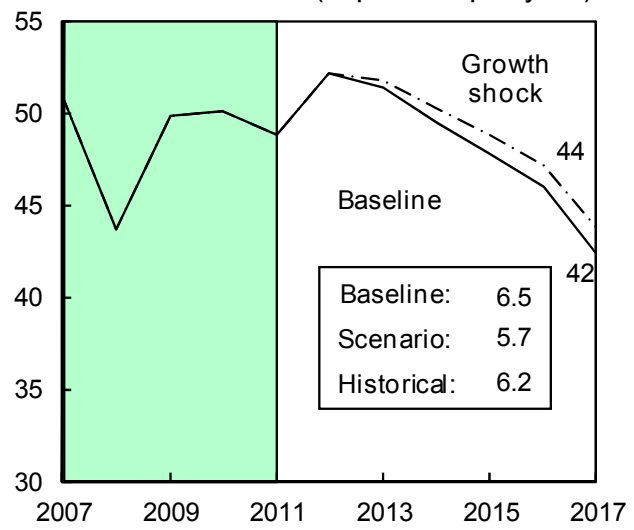

Combined shock $3 /$

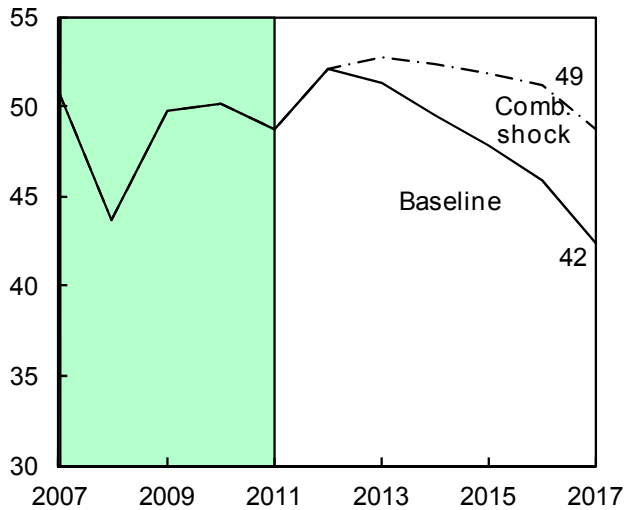

Interest rate shock (in percent)

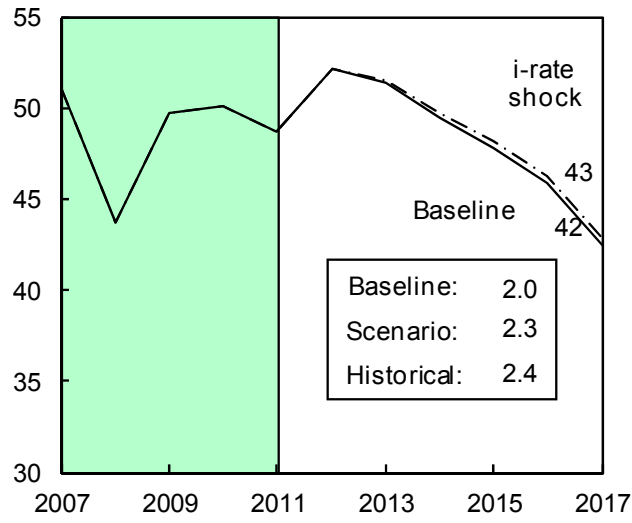

Noninterest current account shock (in percent of GDP)

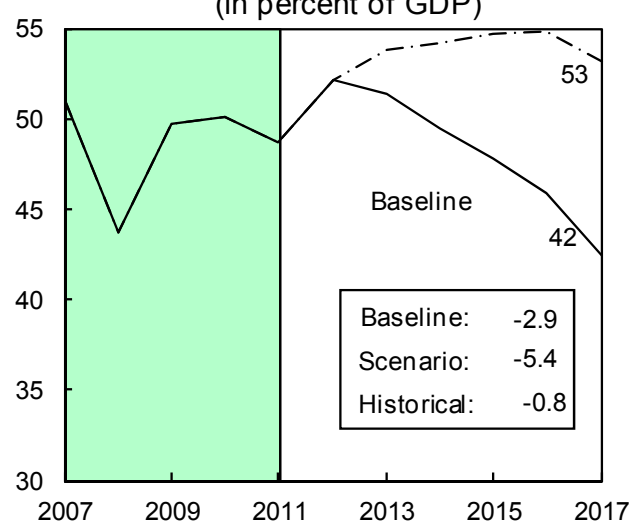

Real depreciation shock 4/

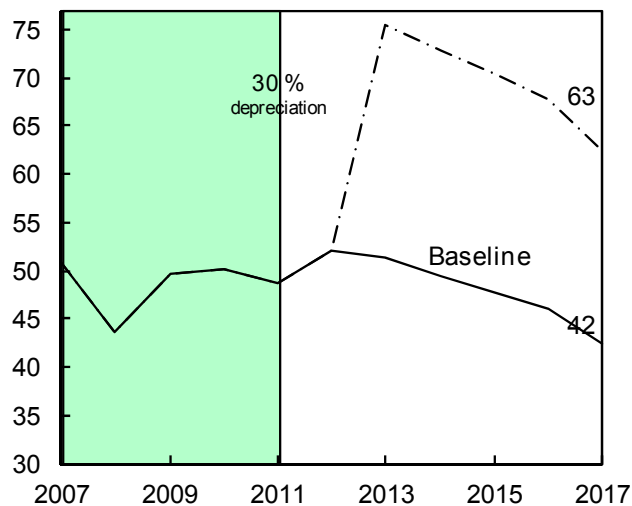

Sources: International Monetary Fund, Country desk data, and staff estimates.

$1 /$ Shaded areas represent actual data. Individual shocks are permanent one-half standard deviation shocks. Figures in the boxes represent average projections for the respective variables in the baseline and scenario being presented. Ten-year historical average for the variable is also shown.

2/ For historical scenarios, the historical averages are calculated over the 10-year period, and the information is used to project debt dynamics five years ahead.

3/ Permanent 1/4 standard deviation shocks applied to real interest rate, growth rate, and current account balance.

4/ One-time real depreciation of 30 percent occurs in 2013. 
Table 1. Sri Lanka: Selected Economic Indicators, 2008-13

\begin{tabular}{|c|c|c|c|c|c|c|}
\hline & 2008 & 2009 & 2010 & 2011 & $\frac{2012}{\text { Proj. }}$ & $\frac{2013}{\text { Proj. }}$ \\
\hline \multicolumn{7}{|l|}{ GDP and inflation (in percent) } \\
\hline Real GDP growth & 6.0 & 3.5 & 8.0 & 8.3 & 6.8 & 6.7 \\
\hline Inflation (average) & 22.4 & 3.5 & 6.2 & 6.7 & 7.7 & 8.2 \\
\hline Inflation (end-of-period) & 13.9 & 5.0 & 6.8 & 4.9 & 9.5 & 7.0 \\
\hline Core inflation (end-of-period) & 10.3 & 5.9 & 8.9 & 5.3 & 7.2 & 6.5 \\
\hline \multicolumn{7}{|l|}{ Public finances (in percent of GDP) } \\
\hline Revenue 1/ & 14.9 & 14.5 & 14.6 & 14.3 & 14.0 & 14.4 \\
\hline Grants 1/ & $\ldots$ & $\ldots$ & 0.3 & 0.2 & 0.3 & 0.2 \\
\hline Expenditure & 22.6 & 24.9 & 22.8 & 21.4 & 20.5 & 20.5 \\
\hline Central government balance $1 /$ & -7.7 & -9.9 & -8.0 & -6.9 & -6.2 & -5.8 \\
\hline Consolidated government balance $1 /$ & -8.1 & -10.3 & -8.5 & -8.6 & -7.3 & -6.4 \\
\hline Central government domestic financing & 7.1 & 5.1 & 4.5 & 4.0 & 3.5 & 3.5 \\
\hline Government debt (domestic and external) & 81.4 & 86.1 & 81.9 & 78.5 & 80.9 & 79.4 \\
\hline \multicolumn{7}{|l|}{ Money and credit (percent change, end of period) } \\
\hline Reserve money & 1.5 & 13.1 & 18.8 & 21.9 & 17.8 & 20.0 \\
\hline Broad money & 8.5 & 18.6 & 14.9 & 20.1 & 17.8 & 18.1 \\
\hline Domestic credit & 18.0 & 3.4 & 15.4 & 34.3 & 18.1 & 12.1 \\
\hline Private sector credit & 7.9 & -6.5 & 24.7 & 34.5 & 20.3 & 14.8 \\
\hline Public sector credit & 46.2 & 23.7 & 0.8 & 33.7 & 13.6 & 6.7 \\
\hline \multicolumn{7}{|l|}{ Balance of payments (in millions of U.S. dollars) } \\
\hline Exports & 8,110 & 7,085 & 8,626 & 10,559 & 10,482 & 11,010 \\
\hline Imports & $-14,467$ & $-10,207$ & $-13,450$ & $-20,213$ & $-20,199$ & $-21,292$ \\
\hline Current account balance & $-4,261$ & -215 & $-1,076$ & $-4,543$ & $-3,201$ & $-3,053$ \\
\hline Current account balance (in percent of GDP) & -10.5 & -0.5 & -2.2 & -7.7 & -5.4 & -4.7 \\
\hline Export value growth (percent) & 6.2 & -12.6 & 21.8 & 22.4 & -0.7 & 5.0 \\
\hline Import value growth (percent) & 28.1 & -29.4 & 31.8 & 50.3 & -0.1 & 5.4 \\
\hline \multicolumn{7}{|l|}{ Gross official reserves (end of period) 2/ } \\
\hline In millions of U.S. dollars & 1,580 & 4,897 & 6,410 & 5,734 & 6,680 & 7,206 \\
\hline In months of imports & 1.6 & 3.9 & 3.5 & 3.1 & 3.4 & 3.4 \\
\hline \multicolumn{7}{|l|}{ External debt (public and private) } \\
\hline In billions of U.S. dollars & 17.8 & 20.9 & 24.8 & 28.8 & 31.1 & 33.2 \\
\hline As a percent of GDP & 43.7 & 49.7 & 50.1 & 48.7 & 52.1 & 51.3 \\
\hline
\end{tabular}

Sources: Data provided by the Sri Lankan authorities; CEIC Data Company Ltd.; Bloomberg L.P.; and IMF staff estimates and projections.

$1 /$ The budget presentation now places grants above the line according to standard practice. Previously grants were classified below the line as a budget deficit financing item. The consolidated government balance includes the Ceylon Electricity Board and the Ceylon Petroleum Corporation.

2/ Excluding central bank Asian Clearing Union (ACU) balances. 
Table 2. Sri Lanka: Summary of Central Government Operations, 2008-13

(In percent of GDP, unless otherwise indicated)

\begin{tabular}{|c|c|c|c|c|c|c|}
\hline & 2008 & 2009 & 2010 & 2011 & 2012 & 2013 \\
\hline & & & & Prel. & Est. & Proj. \\
\hline Total revenue (including grants) & 15.6 & 15.0 & 14.9 & 14.5 & 14.3 & 14.7 \\
\hline Total revenue & 14.9 & 14.5 & 14.6 & 14.3 & 14.0 & 14.4 \\
\hline Tax revenue & 13.3 & 12.8 & 12.9 & 12.4 & 12.5 & 12.8 \\
\hline Income taxes & 2.9 & 2.9 & 2.4 & 2.4 & 2.6 & 2.5 \\
\hline VAT & 4.6 & 3.5 & 3.9 & 3.3 & 3.1 & 3.2 \\
\hline Excise taxes & 2.3 & 2.0 & 2.3 & 2.8 & 2.9 & 3.0 \\
\hline Other trade taxes & 1.8 & 2.0 & 1.3 & 1.4 & 1.6 & 1.6 \\
\hline Other & 1.7 & 2.3 & 2.9 & 2.5 & 2.4 & 2.4 \\
\hline Nontax revenue & 1.6 & 1.7 & 1.7 & 1.9 & 1.5 & 1.6 \\
\hline Grants 1/ & $\ldots$ & 0.5 & 0.3 & 0.2 & 0.3 & 0.2 \\
\hline Total expenditure and net lending & 22.6 & 24.9 & 22.8 & 21.4 & 20.5 & 20.5 \\
\hline Current expenditure & 16.9 & 18.2 & 16.7 & 15.4 & 15.1 & 14.7 \\
\hline Civil service wages and salaries & 3.2 & 3.0 & 2.8 & 2.7 & 2.6 & 2.7 \\
\hline Other civilian goods and services & 1.1 & 1.0 & 0.7 & 0.9 & 1.2 & 1.1 \\
\hline Security expenditure (including contingency) & 3.9 & 3.9 & 3.4 & 3.1 & 2.9 & 2.9 \\
\hline Subsidies and transfers & 3.9 & 3.9 & 3.5 & 3.3 & 3.1 & 3.1 \\
\hline Interest payments & 4.8 & 6.4 & 6.3 & 5.5 & 5.2 & 5.0 \\
\hline Capital expenditure and net lending & 5.7 & 6.7 & 6.1 & 6.0 & 5.5 & 5.8 \\
\hline Overall balance of the central government & -7.7 & -9.9 & -8.0 & -6.9 & -6.2 & -5.8 \\
\hline Financing & 7.7 & 9.9 & 8.0 & 6.9 & 6.2 & 5.8 \\
\hline Net external financing $2 /$ & 0.6 & 4.8 & 3.5 & 2.9 & 2.7 & 2.3 \\
\hline Net domestic financing & 7.1 & 5.1 & 4.5 & 4.0 & 3.5 & 3.5 \\
\hline Privatization & 0.0 & 0.0 & 0.0 & 0.0 & 0.0 & 0.0 \\
\hline \multicolumn{7}{|l|}{ Memorandum items: } \\
\hline Primary balance (excluding grants) & -2.9 & -4.0 & -2.0 & -1.7 & -1.3 & -1.1 \\
\hline Total public debt & 81.1 & 86.1 & 81.9 & 78.5 & 80.9 & 79.4 \\
\hline Domestic debt & 48.3 & 49.7 & 45.8 & 42.9 & 41.1 & 39.3 \\
\hline Foreign debt & 32.8 & 36.4 & 36.1 & 35.6 & 39.8 & 40.1 \\
\hline
\end{tabular}

Sources: Data provided by the Sri Lankan authorities; and IMF staff estimates.

1/ The budget presentation now places grants above the line according to standard practice. Previously grants were classified below the line as a budget deficit financing item.

2 / Includes foreign purchases of treasury bills and bonds. 
Table 3. Sri Lanka: Monetary Accounts, 2008-13

\begin{tabular}{|c|c|c|c|c|c|c|}
\hline & 2008 & 2009 & 2010 & 2011 & 2012 & 2013 \\
\hline & & & & Est. & Proj. & Proj. \\
\hline Monetary authorities & \multicolumn{6}{|c|}{ (Stocks, in billions of Sri Lankan rupees) } \\
\hline Net foreign assets & 148 & 412 & 505 & 340 & 408 & 563 \\
\hline Net domestic assets & 120 & -109 & -145 & 99 & 110 & 58 \\
\hline Of which: Net credit to government & 217 & 109 & 77 & 263 & 315 & 276 \\
\hline \multirow[t]{2}{*}{ Reserve money } & 268 & 304 & 361 & 440 & 518 & 621 \\
\hline & \multicolumn{6}{|c|}{ (Contribution to reserve money growth, in percent) } \\
\hline Net foreign assets & -54.7 & 98.4 & 30.7 & -45.9 & 15.3 & 30.1 \\
\hline Net domestic assets & 56.3 & -85.3 & -12.0 & 67.8 & 2.5 & -10.1 \\
\hline Reserve money (percent change) & 1.5 & 13.1 & 18.8 & 21.9 & 17.8 & 20.0 \\
\hline Monetary survey & \multicolumn{6}{|c|}{ (Stocks, in billions of Sri Lankan rupees) } \\
\hline Net foreign assets & 78 & 402 & 377 & 98 & 107 & 243 \\
\hline Monetary authorities & 148 & 412 & 505 & 340 & 408 & 563 \\
\hline Deposit money banks & -70 & -10 & -128 & -242 & -301 & -321 \\
\hline Net domestic assets & 1,445 & 1,404 & 1,714 & 2,394 & 2,829 & 3,224 \\
\hline Domestic credit & 1,897 & 1,961 & 2,263 & 3,038 & 3,587 & 4,021 \\
\hline Public sector (net) & 619 & 766 & 772 & 1,032 & 1,173 & 1,251 \\
\hline Private sector & 1,278 & 1,196 & 1,491 & 2,006 & 2,414 & 2,770 \\
\hline Other items (net) & -452 & -557 & -549 & -644 & -758 & -797 \\
\hline \multirow[t]{2}{*}{ Broad money } & 1,523 & 1,806 & 2,074 & 2,492 & 2,936 & 3,467 \\
\hline & \multicolumn{6}{|c|}{ (Annual percent change) } \\
\hline Net foreign assets & -65.9 & 417.2 & -6.1 & -74.0 & 9.0 & 127.0 \\
\hline Monetary authorities & -49.4 & 178.2 & 22.6 & -32.7 & 19.8 & 38.2 \\
\hline Deposit money banks & 8.5 & -85.3 & -1140.2 & -89.1 & -24.2 & 6.7 \\
\hline Net domestic assets & 22.9 & -2.8 & 22.1 & 39.7 & 18.2 & 14.0 \\
\hline Domestic credit & 18.0 & 3.4 & 15.4 & 34.3 & 18.1 & 12.1 \\
\hline Public sector (net) & 46.2 & 23.7 & 0.8 & 33.7 & 13.6 & 6.7 \\
\hline Private sector & 7.9 & -6.5 & 24.7 & 34.5 & 20.3 & 14.8 \\
\hline \multirow[t]{2}{*}{ Broad money } & 8.5 & 18.6 & 14.9 & 20.1 & 17.8 & 18.1 \\
\hline & \multicolumn{6}{|c|}{ (Contribution to broad money growth, in percent) } \\
\hline Net foreign assets & -10.7 & 21.3 & -1.4 & -13.5 & 0.4 & 4.6 \\
\hline Net domestic assets & 19.2 & -2.7 & 17.1 & 32.8 & 17.5 & 13.5 \\
\hline Domestic credit & 20.6 & 4.2 & 16.7 & 37.4 & 22.0 & 14.8 \\
\hline Public sector (net) & 13.9 & 9.6 & 0.3 & 12.6 & 5.6 & 2.7 \\
\hline Private sector & 6.7 & -5.4 & 16.3 & 24.8 & 16.4 & 12.1 \\
\hline \multicolumn{7}{|l|}{ Memorandum items: } \\
\hline Broad money multiplier & 5.7 & 6.0 & 5.8 & 5.7 & 5.7 & 5.6 \\
\hline Velocity of broad money & 2.9 & 2.7 & 2.7 & 2.6 & 2.6 & 2.5 \\
\hline
\end{tabular}

Sources: Central Bank of Sri Lanka; and IMF staff projections. 
Table 4. Sri Lanka: Balance of Payments, 2008-13

(In millions of U.S. dollars, unless otherwise indicated)

\begin{tabular}{|c|c|c|c|c|c|c|}
\hline & 2008 & 2009 & 2010 & 2011 & 2012 & 2013 \\
\hline & & & & Est. & Proj & Proj. \\
\hline Current account & $-4,261$ & -215 & $-1,076$ & $-4,543$ & $-3,201$ & $-3,053$ \\
\hline Trade balance & $-6,356$ & $-3,123$ & $-4,824$ & $-9,654$ & $-9,717$ & $-10,282$ \\
\hline Exports & 8,110 & 7,085 & 8,626 & 10,559 & 10,482 & 11,010 \\
\hline Textiles and garments & 3,469 & 3,261 & 3,356 & 4,191 & 4,100 & 4,160 \\
\hline Tea & 1,271 & 1,185 & 1,440 & 1,492 & 1,401 & 1,437 \\
\hline Other & 3,370 & 2,638 & 3,830 & 4,875 & 4,981 & 5,413 \\
\hline Imports & 14,467 & 10,207 & 13,450 & 20,213 & 20,199 & 21,292 \\
\hline Non-oil imports & 11,098 & 8,041 & 10,431 & 15,527 & 15,467 & 16,279 \\
\hline Oil imports & 3,368 & 2,167 & 3,019 & 4,686 & 4,732 & 5,012 \\
\hline Services & 401 & 391 & 705 & 1,099 & 1,493 & 1,748 \\
\hline Receipts & 2,004 & 1,889 & 2,473 & 3,084 & 3,744 & 4,272 \\
\hline Payments & 1,603 & 1,498 & 1,768 & 1,985 & 2,251 & 2,524 \\
\hline Income & -972 & -488 & -617 & -637 & -484 & -463 \\
\hline Transfers & 2,666 & 3,005 & 3,660 & 4,649 & 5,508 & 5,944 \\
\hline Private (net) & 2,565 & 2,927 & 3,608 & 4,605 & 5,447 & 5,864 \\
\hline Remittances & 2,918 & 3,330 & 4,116 & 5,145 & 6,041 & 6,517 \\
\hline Official (net) & 101 & 77 & 52 & 44 & 61 & 80 \\
\hline Capital and financial account & 1,773 & 3,102 & 2,877 & 4,298 & 3,350 & 4,033 \\
\hline Capital transfers (net) & 291 & 233 & 164 & 164 & 174 & 140 \\
\hline Financial account & 1,483 & 2,361 & 2,713 & 4,134 & 3,176 & 3,893 \\
\hline Long-term flows & 1,016 & 1,303 & 2,379 & 3,317 & 3,051 & 3,456 \\
\hline Direct investment & 691 & 384 & 435 & 900 & 1,449 & 1,870 \\
\hline Foreign direct investment & 691 & 384 & 435 & 900 & 1,449 & 1,870 \\
\hline Private sector borrowing 1 / & 74 & 79 & 149 & 153 & -11 & 76 \\
\hline Disbursements & 265 & 390 & 580 & 364 & 451 & 601 \\
\hline Amortization & 191 & 311 & 431 & 211 & 462 & 525 \\
\hline Official sector borrowing & 252 & 840 & 1,795 & 2,264 & 1,613 & 1,510 \\
\hline Disbursements & 1,059 & 1,780 & 2,460 & 3,029 & 2,932 & 2,458 \\
\hline Program loans & 23 & 0 & 40 & 0 & 0 & 0 \\
\hline Project loans & 886 & 1,280 & 1,420 & 2,029 & 1,932 & 2,458 \\
\hline Commercial loans & 150 & 500 & 1,000 & 1,000 & 1,000 & 0 \\
\hline Amortization & 807 & 940 & 665 & 765 & 1,319 & 948 \\
\hline Short-term flows & 466 & 1,058 & 334 & 817 & 125 & 438 \\
\hline Government short-term net & -213 & 1,369 & 531 & 233 & 500 & 250 \\
\hline Nonbank private sector & 594 & 228 & $-1,032$ & 157 & -875 & -500 \\
\hline Banking sector & 26 & -533 & 1,064 & 599 & 550 & 688 \\
\hline Portfolio investment & 60 & -6 & -230 & -172 & -50 & 0 \\
\hline SDR allocation & 0 & 508 & 0 & 0 & 0 & 0 \\
\hline Errors and omissions & 1,103 & -161 & -879 & -816 & $\mathbf{0}$ & $\mathbf{0}$ \\
\hline Overall balance & $-1,385$ & 2,725 & 921 & $-1,061$ & 150 & 980 \\
\hline Financing & 1,385 & $-2,725$ & -921 & 1,061 & -150 & -980 \\
\hline NIR (- = increase) & 1,385 & $-2,725$ & -921 & 1,061 & -150 & -980 \\
\hline Gross reserves & 1,482 & $-3,316$ & $-1,514$ & 676 & -946 & -526 \\
\hline Reserve liabilities (- is outflow) & -97 & 591 & 592 & 385 & 796 & -454 \\
\hline \multicolumn{7}{|l|}{ Memorandum items: } \\
\hline Current account (in percent of GDP) & -10.5 & -0.5 & -2.2 & -7.7 & -5.4 & -4.7 \\
\hline Gross official reserves (net of ACU debit balances) & 1,580 & 4,897 & 6,410 & 5,734 & 6,680 & 7,206 \\
\hline (In months of imports of goods and nonfactor services) & 1.6 & 3.9 & 3.5 & 3.1 & 3.4 & 3.4 \\
\hline (In percent of short-term debt) & 35 & 79 & 100 & 70 & 86 & 84 \\
\hline Net international reserves & 1,425 & 4,150 & 5,072 & 4,011 & 4,161 & 5,141 \\
\hline Short-term debt and amortizaton (US\$ millions, residual maturity) & 4,572 & 6,183 & 6,397 & 8,154 & 7,793 & 8,576 \\
\hline
\end{tabular}

Sources: Data provided by the Central Bank of Sri Lanka; and IMF staff estimates and projections.

$1 /$ Includes public corporations. 
Table 5. Sri Lanka: Preliminary External Financing Requirements, 2008-13

(In millions of U.S. dollars, unless otherwise indicated)

\begin{tabular}{|c|c|c|c|c|c|c|}
\hline & 2008 & 2009 & 2010 & 2011 & 2012 & 2013 \\
\hline & & & & Est. & Proj. & Proj. \\
\hline Current account, including official transfers & $-4,261$ & -215 & $-1,076$ & $-4,543$ & $-3,201$ & $-3,053$ \\
\hline (In percent of GDP) & -10.5 & -0.5 & -2.2 & -7.7 & -5.4 & -4.7 \\
\hline Trade balance & $-6,356$ & $-3,123$ & $-4,824$ & $-9,654$ & $-9,717$ & $-10,282$ \\
\hline Exports & 8,110 & 7,085 & 8,626 & 10,559 & 10,482 & 11,010 \\
\hline Imports & 14,467 & 10,207 & 13,450 & 20,213 & 20,199 & 21,292 \\
\hline Private transfers & 2,565 & 2,927 & 3,608 & 4,605 & 5,447 & 5,864 \\
\hline Other & -470 & -20 & 140 & 506 & 1,070 & 1,365 \\
\hline Amortization & $-1,095$ & $-1,353$ & $-1,124$ & -985 & $-1,829$ & $-1,927$ \\
\hline Public sector & -807 & -940 & -665 & -765 & $-1,319$ & -948 \\
\hline IMF & -97 & -102 & -28 & -9 & -48 & -454 \\
\hline Private sector & -191 & -311 & -431 & -211 & -462 & -525 \\
\hline Change in NFA of commercial banks (- = an increase) & 26 & -533 & 1064 & 599 & 550 & 688 \\
\hline Change in official reserves (- $=$ an increase) & 1,482 & $-3,316$ & $-1,514$ & 676 & -946 & -526 \\
\hline Gross external financing requirement & $-3,848.8$ & $-5,416.7$ & $-2,650.1$ & $-4,253.5$ & $-5,425.5$ & $-4,818.8$ \\
\hline (In percent of GDP) & -9.5 & -12.9 & -5.3 & -7.2 & -9.1 & -7.4 \\
\hline Sources of financing & 3,849 & 4,724 & 2,029 & 3,859 & 4,581 & 4,819 \\
\hline Borrowing & 1,324 & 2,170 & 3,040 & 3,393 & 3,383 & 3,059 \\
\hline Official sector financing commitments & 1,059 & 1,780 & 2,460 & 3,029 & 2,932 & 2,458 \\
\hline Official sector borrowing & 1,059 & 1,780 & 2,460 & 3,029 & 2,932 & 2,458 \\
\hline Syndicated/commerical loans & 150 & 500 & 1,000 & 1,000 & 1,000 & 0 \\
\hline Private sector borrowing & 265 & 390 & 580 & 364 & 451 & 601 \\
\hline Other capital account & 2,525 & 2,046 & $-1,011$ & 466 & 1,198 & 1,760 \\
\hline Capital transfers & 291 & 233 & 164 & 164 & 174 & 140 \\
\hline FDI inflows & 691 & 384 & 435 & 900 & 1449 & 1870 \\
\hline Other (including errors and omissions) & 1,544 & 1,429 & $-1,610$ & -598 & -425 & -250 \\
\hline Rupee denominated T-bonds & -213 & 1,369 & 531 & 233 & 500 & 250 \\
\hline Nonbank private sector (including trade credits) & 594 & 228 & $-1,032$ & 157 & -875 & -500 \\
\hline Portfolio investment & 60 & -6 & -230 & -172 & -50 & 0 \\
\hline Errors and omission & 1,103 & -161 & -879 & -816 & 0 & 0 \\
\hline SDR allocation & 0 & 508 & 0 & 0 & 0 & 0 \\
\hline External financing gap=IMF financing & 0 & -693 & -621 & -394 & -844 & $\mathbf{0}$ \\
\hline Gross official reserves of the Central Bank of Sri Lanka & 1,580 & 4,897 & 6,410 & 5,734 & 6,680 & 7,206 \\
\hline (In months of imports of goods and nonfactor services) & 1.6 & 3.9 & 3.5 & 3.1 & 3.4 & 3.4 \\
\hline
\end{tabular}

Sources: Sri Lankan authorities; and IMF staff estimates and projections. 
Table 6. Sri Lanka: Financial Soundness Indicators-All Banks, 2008-12

\begin{tabular}{|c|c|c|c|c|c|}
\hline & 2008 & 2009 & 2010 & 2011 & $\begin{array}{l}2012 \\
\text { April 1/ }\end{array}$ \\
\hline \multicolumn{6}{|l|}{ Capital adequacy } \\
\hline Regulatory capital to risk weighted assets & 13.5 & 16.1 & 16.2 & 15.2 & 14.9 \\
\hline Tier 1 capital/risk weighted assets & 11.5 & 14.1 & 14.3 & 13.6 & 13.3 \\
\hline Net nonperforming loans to total capital funds & 18.4 & 26.2 & 15.2 & 11.5 & 13.7 \\
\hline Debt to capital funds & 210.1 & 160.1 & 172.0 & 168.7 & 184.0 \\
\hline Capital to assets ratio & 8.2 & 8.1 & 8.3 & 8.7 & 8.5 \\
\hline \multicolumn{6}{|l|}{ Asset quality } \\
\hline \multicolumn{6}{|l|}{ Gross nonperforming loans to total gross loans } \\
\hline (without interest in suspense) & 6.3 & 8.5 & 5.4 & 3.8 & 4.0 \\
\hline \multicolumn{6}{|l|}{ Gross nonperforming loans to total gross loans } \\
\hline (with interest in suspense) & 8.1 & 10.7 & 7.3 & 6.1 & 6.2 \\
\hline Net nonperforming loans to total gross loans & 3.4 & 5.0 & 3.0 & 1.7 & 2.0 \\
\hline Provision coverage ratio (total) & 60.9 & 53.0 & 58.1 & 56.7 & 52.1 \\
\hline \multicolumn{6}{|l|}{ Earnings and profitability } \\
\hline Return on equity (after tax) & 13.4 & 11.8 & 22.2 & 19.8 & 21.1 \\
\hline Return on assets (after tax) & 1.1 & 1.0 & 1.8 & 1.7 & 1.8 \\
\hline Interest income to gross income & 86.3 & 86.0 & 83.1 & 85.7 & 82.9 \\
\hline Staff expenses to noninterest expenses & 44.5 & 46.5 & 45.2 & 43.8 & 44.2 \\
\hline Personnel expenses to total income & 9.9 & 10.6 & 12.0 & 12.1 & 11.3 \\
\hline Total cost to total income & 79.8 & 78.1 & 71.9 & 73.9 & 71.7 \\
\hline Interest margin & 4.4 & 4.6 & 4.6 & 4.2 & 4.1 \\
\hline \multicolumn{6}{|l|}{ Liquidity } \\
\hline Liquid assets to total assets & 28.2 & 35.3 & 31.4 & 26.9 & 27.7 \\
\hline Statutory liquid assets ratio-domestic banking units & 31.3 & 39.2 & 36.6 & 32.4 & 32.6 \\
\hline \multicolumn{6}{|l|}{ Assets/funding structure } \\
\hline Deposits & 69.6 & 74.1 & 72.8 & 72.4 & 71.2 \\
\hline Borrowings & 17.0 & 12.9 & 14.3 & 14.7 & 15.6 \\
\hline Capital to external funds & 9.4 & 9.3 & 9.5 & 10.0 & 9.8 \\
\hline Credit to deposits & 87.0 & 71.5 & 76.4 & 84.5 & 84.6 \\
\hline
\end{tabular}

Source: Central Bank of Sri Lanka.

1/ Provisional. 
Table 7. Sri Lanka: Projected Payments to the Fund, 2011-17

(In millions of SDR, unless otherwise indicated)

\begin{tabular}{|c|c|c|c|c|c|c|c|}
\hline & 2011 & 2012 & 2013 & 2014 & 2015 & 2016 & 2017 \\
\hline \multicolumn{8}{|l|}{ Fund repurchases and charges } \\
\hline In millions of SDR & 20.1 & 44.8 & 322.5 & 488.5 & 370.7 & 331.6 & 173.5 \\
\hline In millions of U.S. dollars & 31.0 & 68.4 & 509.2 & 748.0 & 564.5 & 504.7 & 263.9 \\
\hline In percent of exports of goods and NFS & 0.2 & 0.5 & 3.3 & 4.5 & 3.0 & 2.4 & 1.1 \\
\hline In percent of quota & 4.9 & 10.8 & 78.0 & 118.2 & 89.7 & 80.2 & 42.0 \\
\hline In percent of gross official reserves & 0.5 & 1.0 & 7.1 & 9.3 & 6.0 & 4.7 & 2.0 \\
\hline \multicolumn{8}{|l|}{ Fund credit outstanding } \\
\hline In millions of SDR & $1,119.5$ & $1,639.3$ & $1,340.9$ & 867.2 & 505.5 & 178.2 & 6.0 \\
\hline In millions of U.S. dollars & $1,726.9$ & $2,501.6$ & $2,117.0$ & $1,328.0$ & 769.8 & 271.2 & 9.1 \\
\hline In percent of quota & 270.8 & 396.5 & 324.4 & 209.8 & 122.3 & 43.1 & 1.4 \\
\hline In percent of GDP & 2.9 & 4.2 & 3.3 & 1.9 & 1.0 & 0.3 & 0.01 \\
\hline In percent of gross official reserves & 30.1 & 37.4 & 29.4 & 16.4 & 8.2 & 2.5 & 0.1 \\
\hline \multicolumn{8}{|l|}{ Memorandum items: } \\
\hline Exports of goods and services (millions of U.S. dollars) & 13,643 & 14,226 & 15,282 & 16,764 & 18,579 & 20,643 & 23,000 \\
\hline Quota (millions of SDR) & 413 & 413 & 413 & 413 & 413 & 413 & 413 \\
\hline Quota (millions of U.S. dollars) & 638 & 631 & 653 & 633 & 630 & 629 & 629 \\
\hline Gross official reserves (in millions of U.S. dollars) & 5,734 & 6,680 & 7,206 & 8,075 & 9,396 & 10,778 & 13,306 \\
\hline
\end{tabular}

Source: IMF staff estimates. 
Table 8. Sri Lanka: Reviews and Disbursements Under the Stand-By Arrangement

\begin{tabular}{|c|c|c|c|c|}
\hline \multirow[b]{2}{*}{ Date } & \multicolumn{3}{|c|}{ Amount of Purchase } & \multirow[b]{2}{*}{ Condition } \\
\hline & $\begin{array}{c}\text { In percent } \\
\text { of quota }\end{array}$ & In SDRs & In USD & \\
\hline July 24, 2009 & 50 & 206.7 & 314.1 & Approved SBA \\
\hline November 6, 2009 & 50 & 206.7 & 314.1 & $\begin{array}{l}\text { Completion of the first review } \\
\text { and observance of relevant } \\
\text { performance criteria }\end{array}$ \\
\hline June 28,2010 & 67 & 275.6 & 418.8 & $\begin{array}{l}\text { Completion of the second } \\
\text { and third review and observance } \\
\text { of relevant performance criteria }\end{array}$ \\
\hline September 24, 2010 & 33 & 137.8 & 209.4 & $\begin{array}{l}\text { Completion of the fourth review } \\
\text { and observance of relevant } \\
\text { performance criteria }\end{array}$ \\
\hline February 2, 2011 & 33 & 137.8 & 209.4 & $\begin{array}{l}\text { Completion of the fifth review } \\
\text { and observance of relevant } \\
\text { performance criteria }\end{array}$ \\
\hline April 4, 2011 & 33 & 137.8 & 209.4 & $\begin{array}{l}\text { Completion of the sixth review } \\
\text { and observance of relevant } \\
\text { performance criteria }\end{array}$ \\
\hline April 2, 2012 & 67 & 275.6 & 418.8 & $\begin{array}{l}\text { Completion of the seventh review } \\
\text { and observance of relevant } \\
\text { performance criteria }\end{array}$ \\
\hline July 20, 2012 & 67 & 275.6 & 418.8 & $\begin{array}{l}\text { Completion of the eighth review } \\
\text { and observance of relevant } \\
\text { performance criteria }\end{array}$ \\
\hline Total & 400 & $1,653.6$ & $2,513.1$ & \\
\hline
\end{tabular}

Note: USD amounts are based on the exchange rate for USD/SDR as of June 15, 2012. 
Table 9. Sri Lanka: Public Sector Debt Sustainability Framework, 2007-17

(In percent of GDP, unless otherwise indicated)

\begin{tabular}{|c|c|c|c|c|c|c|c|c|c|c|c|}
\hline & \multicolumn{5}{|c|}{ Actual } & \multicolumn{6}{|c|}{ Projections } \\
\hline & 2007 & 2008 & 2009 & 2010 & 2011 & 2012 & 2013 & 2014 & 2015 & 2016 & 2017 \\
\hline Baseline: Public sector debt 1 / & 85.0 & 81.4 & 86.1 & 81.9 & 78.5 & 80.9 & 79.4 & 77.0 & 74.7 & 72.4 & 68.4 \\
\hline Change in public sector debt & -2.9 & -3.6 & 4.7 & -4.2 & -3.4 & 2.4 & -1.5 & -2.4 & -2.4 & -2.2 & -4.0 \\
\hline Identified debt-creating flows $(4+7+12)$ & -7.6 & -7.1 & 3.6 & -4.5 & -3.8 & 1.0 & -2.2 & -2.3 & -2.3 & -2.3 & -2.2 \\
\hline Primary deficit & 2.6 & 2.9 & 4.0 & 2.0 & 1.7 & 1.3 & 1.1 & 0.6 & 0.4 & 0.3 & 0.1 \\
\hline Revenue and grants & 15.8 & 14.9 & 14.5 & 14.6 & 14.3 & 14.0 & 14.4 & 14.8 & 14.9 & 15.0 & 15.1 \\
\hline Primary (noninterest) expenditure & 18.4 & 17.8 & 18.5 & 16.6 & 15.9 & 15.3 & 15.5 & 15.4 & 15.3 & 15.3 & 15.3 \\
\hline Automatic debt dynamics $2 /$ & -10.2 & -10.0 & -0.4 & -6.5 & -5.4 & -0.3 & -3.3 & -2.9 & -2.7 & -2.6 & -2.4 \\
\hline Contribution from interest rate/growth differential 3/ & -10.6 & -11.2 & -0.7 & -5.5 & -6.3 & -4.9 & -5.5 & -4.7 & -4.0 & -3.8 & -3.5 \\
\hline Of which: Contribution from real interest rate & -5.7 & -7.1 & 1.9 & 0.4 & -0.5 & -0.3 & -0.8 & -0.2 & 0.5 & 0.5 & 0.7 \\
\hline Of which: Contribution from real GDP growth & -4.9 & -4.1 & -2.6 & -5.9 & -5.8 & -4.6 & -4.7 & -4.5 & -4.4 & -4.3 & -4.2 \\
\hline Contribution from exchange rate depreciation 4/ & 0.4 & 1.2 & 0.4 & -1.0 & 0.9 & 4.6 & 2.2 & 1.8 & 1.3 & 1.2 & 1.2 \\
\hline Other identified debt-creating flows & 0.0 & 0.0 & 0.0 & 0.0 & 0.0 & 0.0 & 0.0 & 0.0 & 0.0 & 0.0 & 0.0 \\
\hline Privatization receipts (negative) & 0.0 & 0.0 & 0.0 & 0.0 & 0.0 & 0.0 & 0.0 & 0.0 & 0.0 & 0.0 & 0.0 \\
\hline Recognition of implicit or contingent liabilities & 0.0 & 0.0 & 0.0 & 0.0 & 0.0 & 0.0 & 0.0 & 0.0 & 0.0 & 0.0 & 0.0 \\
\hline Other (specify, e.g., bank recapitalization) & 0.0 & 0.0 & 0.0 & 0.0 & 0.0 & 0.0 & 0.0 & 0.0 & 0.0 & 0.0 & 0.0 \\
\hline Residual, including asset changes (2-3) 5/ & 4.7 & 3.5 & 1.1 & 0.4 & 0.3 & 6.1 & 2.9 & 1.8 & 1.2 & 1.3 & -0.6 \\
\hline Public sector debt-to-revenue ratio $1 /$ & 538.3 & 547.7 & 594.8 & 561.6 & 549.1 & 578.7 & 550.1 & 522.2 & 500.8 & 482.9 & 451.9 \\
\hline Gross financing need 6 / & 24.9 & 25.1 & 31.6 & 27.5 & 27.4 & 26.2 & 22.3 & 19.3 & 17.9 & 16.0 & 14.0 \\
\hline Scenario with key variables at their historical averages $7 /$ & & & & & & 80.9 & 79.9 & 77.9 & 75.4 & 73.3 & 69.3 \\
\hline Scenario with no policy change (constant primary balance) in 2012-17 & & & & & & 80.9 & 79.6 & 77.9 & 76.4 & 75.1 & 72.2 \\
\hline \multicolumn{12}{|l|}{ Key macroeconomic and fiscal assumptions underlying baseline } \\
\hline Real GDP growth (in percent) & 6.8 & 6.0 & 3.5 & 8.0 & 8.3 & 6.8 & 6.7 & 6.5 & 6.5 & 6.5 & 6.5 \\
\hline Average nominal interest rate on public debt (in percent) 8/ & 7.1 & 7.0 & 8.6 & 8.5 & 7.8 & 7.7 & 7.1 & 7.0 & 6.9 & 7.0 & 7.1 \\
\hline Average real interest rate (nominal rate minus change in GDP deflator, in percent) & -7.0 & -9.3 & 2.7 & 1.2 & -0.1 & 0.1 & -0.6 & 0.1 & 1.0 & 1.2 & 1.4 \\
\hline Nominal appreciation (increase in US dollar value of local currency, in percent) & -1.1 & -3.8 & -1.2 & 3.1 & -2.6 & $\ldots$ & $\ldots$ & $\ldots$ & $\ldots$ & $\ldots$ & $\ldots$ \\
\hline Inflation rate (GDP deflator, in percent) & 14.0 & 16.3 & 5.9 & 7.3 & 7.8 & 7.6 & 7.6 & 6.8 & 5.9 & 5.9 & 5.7 \\
\hline Growth of real primary spending (deflated by GDP deflator, in percent) & 2.7 & 2.2 & 7.5 & -3.1 & 4.3 & 2.2 & 8.5 & 5.4 & 6.1 & 6.1 & 6.5 \\
\hline Primary deficit & 2.6 & 2.9 & 4.0 & 2.0 & 1.7 & 1.3 & 1.1 & 0.6 & 0.4 & 0.3 & 0.1 \\
\hline
\end{tabular}

1/ Indicate coverage of public sector, e.g., general government or nonfinancial public sector. Also whether net or gross debt is used.

$2 /$ Derived as $[(r-p(1+g)-g+a e(1+r)] /(1+g+p+g p))$ times previous period debt ratio, with $r=$ interest rate; $p=$ growth rate of GDP deflator; $g=$ real GDP growth rate; $a=$ share of foreign-currency denominated debt; and $\mathrm{e}=$ nominal exchange rate depreciation (measured by increase in local currency value of U.S. dollar).

3 The real interest rate contribution is derived from the denominator in footnote $2 /$ as $r-\pi(1+g)$ and the real growth contribution as $-g$

$4 /$ The exchange rate contribution is derived from the numerator in footnote $2 /$ as ae $(1+r)$.

5/ For projections, this line includes exchange rate changes.

6/ Defined as public sector deficit, plus amortization of medium and long-term public sector debt, plus short-term debt at end of previous period.

7/ The key variables include real GDP growth; real interest rate; and primary balance in percent of GDP.

8/ Derived as nominal interest expenditure divided by previous period debt stock. 
Table 10. Sri Lanka: External Debt Sustainability Framework, 2007-17

(In percent of GDP, unless otherwise indicated)

\begin{tabular}{|c|c|c|c|c|c|c|c|c|c|c|c|}
\hline & \multicolumn{4}{|c|}{ Actual } & \multirow[b]{2}{*}{2011} & \multicolumn{6}{|c|}{ Projections } \\
\hline & 2007 & 2008 & 2009 & 2010 & & 2012 & 2013 & 2014 & 2015 & 2016 & 2017 \\
\hline Baseline: External debt & 50.9 & 43.7 & 49.7 & 50.1 & 48.7 & 52.1 & 51.3 & 49.5 & 47.8 & 45.9 & 42.4 \\
\hline Change in external debt & 1.5 & -7.3 & 6.1 & 0.4 & -1.4 & 3.4 & -0.8 & -1.9 & -1.7 & -1.9 & -3.5 \\
\hline Identified external debt-creating flows $(4+8+9)$ & -4.1 & -0.9 & -1.9 & -7.1 & -2.8 & -0.3 & -1.4 & -2.0 & -2.1 & -2.6 & -2.8 \\
\hline Current account deficit, excluding interest payments & 3.0 & 9.4 & -0.3 & 1.1 & 6.5 & 4.4 & 3.8 & 3.5 & 3.1 & 2.5 & 1.9 \\
\hline Deficit in balance of goods and services & -68.5 & -64.3 & -49.2 & -53.1 & -60.6 & -61.4 & -60.4 & -60.5 & -60.6 & -60.7 & -61.0 \\
\hline Exports & 29.1 & 24.8 & 21.3 & 22.4 & 23.1 & 23.8 & 23.6 & 23.9 & 24.3 & 24.7 & 25.3 \\
\hline Imports & -39.4 & -39.5 & -27.8 & -30.7 & -37.5 & -37.6 & -36.8 & -36.6 & -36.3 & -36.0 & -35.7 \\
\hline Net non-debt-creating capital inflows (negative) & -2.1 & -0.9 & -1.0 & -1.8 & -2.5 & -2.4 & -2.9 & -3.3 & -3.2 & -3.1 & -2.9 \\
\hline Automatic debt dynamics $1 /$ & -4.9 & -9.3 & -0.6 & -6.4 & -6.9 & -2.3 & -2.3 & -2.2 & -2.0 & -1.9 & -1.9 \\
\hline Contribution from nominal interest rate & 1.4 & 1.1 & 0.8 & 1.1 & 1.2 & 1.0 & 1.0 & 0.9 & 1.0 & 0.9 & 0.9 \\
\hline Contribution from real GDP growth & -2.9 & -2.4 & -1.5 & -3.4 & -3.5 & -3.3 & -3.2 & -3.1 & -2.9 & -2.9 & -2.7 \\
\hline Contribution from price and exchange rate changes 2/ & -3.3 & -8.0 & 0.1 & -4.1 & -4.6 & 2.3 & -1.1 & -1.2 & -1.3 & -1.3 & -1.1 \\
\hline Residual, including change in gross foreign assets (2-3) 3 / & 5.6 & -6.4 & 8.0 & 7.5 & 1.4 & 1.4 & 1.6 & 1.3 & 1.8 & 1.9 & 0.5 \\
\hline External debt-to-exports ratio (in percent) & 175.1 & 175.8 & 233.1 & 223.7 & 211.3 & 218.8 & 217.3 & 207.1 & 197.0 & 185.6 & 167.6 \\
\hline Gross external financing need (in billions of U.S. dollars) 4/ & 4.8 & 8.9 & 5.6 & 7.5 & 11.5 & 11.9 & 11.4 & 12.3 & 12.6 & 13.7 & 13.9 \\
\hline In percent of GDP & 14.9 & 21.8 & 13.3 & 15.2 & 19.5 & 20.0 & 17.7 & 17.5 & 16.5 & 16.5 & 15.3 \\
\hline Scenario with key variables at their historical averages 5 / & & & & & & 52.1 & 47.4 & 42.9 & 39.2 & 36.0 & 31.8 \\
\hline \multicolumn{12}{|l|}{ Key macroeconomic assumptions underlying baseline } \\
\hline Real GDP growth (in percent) & 6.8 & 6.0 & 3.5 & 8.0 & 8.3 & 6.7 & 6.7 & 6.5 & 6.5 & 6.5 & 6.5 \\
\hline GDP deflator in U.S. dollars (change in percent) & 7.2 & 18.7 & -0.3 & 9.1 & 10.3 & -5.5 & 1.6 & 1.9 & 2.4 & 2.4 & 2.2 \\
\hline Nominal external interest rate (in percent) & 3.2 & 2.7 & 2.0 & 2.6 & 2.8 & 2.0 & 2.0 & 2.0 & 2.1 & 2.1 & 2.1 \\
\hline Growth of exports (U.S. dollar terms, in percent) & 10.7 & 7.4 & -11.3 & 23.7 & 22.9 & 4.3 & 7.4 & 9.7 & 10.8 & 11.1 & 11.4 \\
\hline Growth of imports (U.S. dollar terms, in percent) & 9.8 & 25.9 & -27.2 & 30.0 & 45.9 & 1.1 & 6.1 & 8.0 & 8.0 & 8.2 & 7.9 \\
\hline Current account balance, excluding interest payments & -3.0 & -9.4 & 0.3 & -1.1 & -6.5 & -4.4 & -3.8 & -3.5 & -3.1 & -2.5 & -1.9 \\
\hline
\end{tabular}

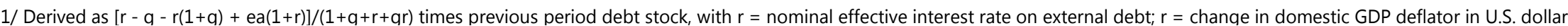
terms, $\mathrm{q}=$ real GDP growth rate, $\mathrm{e}=$ nominal appreciation (increase in dollar value of domestic currency), and a = share of domestic-currency denominated debt in total external debt. $2 /$ The contribution from price and exchanqe rate changes is defined as $[-r(1+q)+e a(1+r)] /(1+q+r+q r)$ times previous period debt stock. $r$ increases with an appreciating domestic currency (e > 0) and rising inflation (based on GDP deflator).

3 / For projection, line includes the impact of price and exchange rate changes.

4/ Defined as current account deficit, plus amortization on medium- and long-term debt, plus short-term debt at end of previous period.

5/ The key variables include real GDP growth; nominal interest rate; dollar deflator qrowth; and both noninterest current account and nondebt inflows in percent of GDP. 


\section{ATtAChMEnT I \\ SRI LANKA: LETTER OF INTENT}

July 05,2012

Ms. Christine Lagarde

Managing Director

International Monetary Fund

Washington, DC 20431

Dear Ms. Lagarde:

This letter supplements the Memorandum of Economic and Financial Policies of July 16, 2009, and the Letters of Intent dated October 30, 2009; June 19, 2010; September 14, 2010; January 17, 2011; March 15, 2011; and March 15, 2012.

1. Since the end of the conflict in 2009, the Sri Lankan economy has recorded undeniable success, supported by an IMF Stand-By Arrangement (SBA). Growth averaged over 8 percent in 2010 and 2011, inflation was brought down to the single digits and kept there for the longest period in our modern economic history, the fiscal deficit was steadily reduced, helping the debt-GDP ratio to decline, and international reserves at the central bank were built up dramatically.

2. But as the economy grew, so too did imports, fueled by rapid credit growth and rising oil prices, and despite the strong performance of exports and remittances, the current account deficit widened sharply last year, putting pressure on our reserves. While continuing our efforts to mobilize foreign capital inflows to finance this deficit, in February we also adopted a bold package of measures to contain the deficit and thus reduce the financing need. These measures included: (i) the pursuance of greater exchange rate flexibility, as we scaled back foreign-exchange intervention; (ii) a tightening of monetary policy through rate hikes and the pursuance of strategies to moderate bank credit growth; (iii) a further consolidation of fiscal policy via an increase in duties and an adjustment in energy prices to reflect international developments, which also helped to address state enterprise losses; and (iv) a general commitment to use all of these policy levers flexibly, as required by changing economic circumstances. 
3. Though only a few months old, the policy package has already delivered clear results. Credit growth has slowed, import growth has turned negative, and the current account deficit has narrowed. At the same time, banks have raised substantial amounts of capital abroad, there appear to be strong prospects for issuing another sovereign Eurobond in the near future, and substantial foreign inflows into the stock market have materialized. The overall balance of payments should thus register a surplus in 2012, helping us increase reserves levels once again. Further, the policy measures taken have strengthened our economic fundamentals, improved our ability to absorb shocks, and laid the basis for continued strong performance in years to come. Inflation may increase and growth slow in the near term, however, the policy measures undertaken should ease inflationary pressures going forward, and help us to cope with the global risks and their possible impact on our economy. In this context, we will maintain exchange-rate flexibility as this provides a key buffer to external shocks.

4. Though easing growth and imports have dampened budget revenue collection, we remain committed to achieving our 2012 budget deficit target of 6.2 percent of GDP through expenditure control and some revenue measures. More fundamentally, we recognize the need to strengthen revenue administration, particularly with respect to the VAT, and public financial management processes.

5. Coming to the program targets, the end-June performance criterion on net international reserves was observed, despite highly unfavorable valuation changes on the central bank's portfolio of foreign assets and accelerated repayment of oil imports credit lines. Latest data suggest the reserve money target will also have been met. Slower growth and higher interest rates have put pressure on fiscal performance, but available data indicate we nonetheless will have met the end-June benchmark on net domestic financing of the budget deficit. Cabinet approval of amendments to the Petroleum Act (structural benchmark) was received in April. Given this strong performance against program targets and our continued commitment to flexible macroeconomic policy management, we request completion of the eighth and final review of the SBA.

6. We are very pleased to bring this program to a successful conclusion. The SBA has helped us to strengthen our economy and to communicate those strengths to the outside world, and we look forward to continued, close engagement with the IMF. The precise modalities have yet to be worked out, but we intend to discuss with IMF staff the possibility of financial support for our economic development agenda under an Extended Fund Facility. This would continue to prioritize macroeconomic and financial stability and growth through prudent monetary and fiscal policies, while also addressing pressing concerns such as state enterprise performance, revenue administration, and public financial management. 
7. We believe that the policies set forth in this and previous Letters of Intent are adequate to achieve the objectives of our economic program, and we stand ready to take additional measures as appropriate to ensure achievement of the objectives. We will continue to liaise with the IMF when modifying measures contained in this letter, or adopting measures that would deviate from program goals, and provide the IMF with the information necessary for program monitoring.

8. In keeping with its policy of transparency, the Government has authorized the publication of this letter and the attached Technical Memorandum of Understanding.

Yours sincerely,

/s/

Gitanjana Gunawardena

Deputy Minister of Finance and Planning /s/

Ajith Nivard Cabraal

Governor, Central Bank of Sri Lanka 
End-Mar. Indicative Targets

7th Review Adj. Prel. $\quad$ 8th Review Adj. Prel.

Quantitative performance criteria and indicative targets

Net international Reserves (NIR) of the Central Bank of Sri Lanka (CBSL) (floor, cumulative change from the beginning of the year, in million US\$) $1 / 2 / 3 / 4 / 5 /$

Reserve money of the CBSL (ceiling, eop stock, in million rupees)

Net domestic financing (NDF) of the central government from the banking syste and the non-bank sector (celing cus from the beginning of the year, in million rupees) $6 / 7 / 8 / 9 / 10 /$

Continous performance criteria

Accumulation of new external payment arrears (ceiling, eop, in million US\$)

Indicative targets

Overall balance of the Ceylon Petroleum Corporation and the Ceylon Electricity Board (floor, cumulative from the beginning of the year, in million rupees) $11 /$

Memorandum items:

External debt service assumed under the program (cumulative from the beginning of the year, in million rupees) 7/

Privatization proceeds to the central government in connection with the sale of central government assets (in million rupees) 8/

Outstanding claims by the Bank of Ceylon on the central government (item VIII $(e, 1)$ on the balance sheet of the Bank of Ceylon, in million rupees) 9

Foreign program financing assumed under the program (cumulative from the beginning of the year, in million US\$)

External commercial loans (including Eurobonds and syndicated loans) assumed under the program (cumulative from the beginning of the year, in million US\$) 21

Cumulative net inflows into the Treasury Bill and Treasury Bond market assumed under the program (cumulative from the

Cumulative net inflows into the Treasury

Official external debt service assumed under the program (cumulative from the beginning of the year, in million US\$) $3 /$

Settlement of syndicated loans assumed under the program (cumulative from the beginning of the year, in million US\$) $4 /$

Outstanding value (i.e., receivables) on swaps and forwards by CBSL (eop stock, in million US\$) 5 /

$\begin{array}{rr}2,725 & 921 \\ 303,500 & 358,869 \\ 392,476 & 242,259\end{array}$

44

$-1,061$
$442,436 \quad 468,5$

$-684$

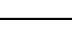

0
$-19,400$

60

$-415$

$-251$

$-670$

$-574$

Prel.

$\begin{array}{rrr}141,914 & 108,607 & 132,41 \\ 0 & 0 & \\ 6,038 & 1,575 & 1,575 \\ 0 & 40 & \\ 500 & 1,000 & 1,000 \\ 1,345 & 467 & 232 \\ 878 & 874 & 1,072 \\ 225 & 25 & \\ 245 & 97 & \end{array}$

468,500
230,814

485,802
248,992

485,802
248,992

-670
474,165
300,478

$-574$

$-324$

462,319

296,167

0

$-113,800$

132,411

0

1,575

000

.072

0

0

1/ If the cu 2/If the armor.

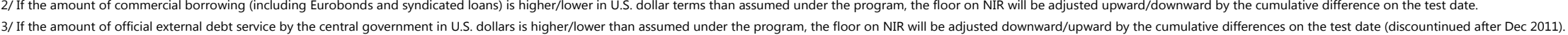

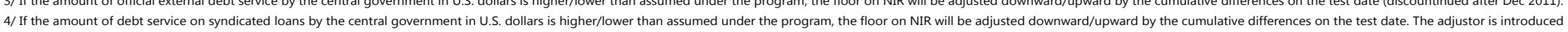

f If the amount of debt service on syndicated loans by the central government in U.S. dollars is higher/lower than assumed under the program, the floor on NIR will be adjusted downward/upward by the cumulative differences on the test date. The adjustor is introduced
$5 /$ If the outstanding value on swaps and forwards is higher/lower than assumed under the program, the floor on NIR will be adjusted upward/downward by the difference on the test date. This adjustor is introduced from end-March 2012. The outstanding value as of

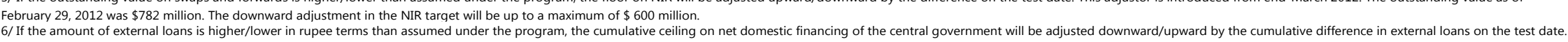
From end-December, external loans will be defined as external program loans and external commercial loans (including Eurobonds and syndicated loans).

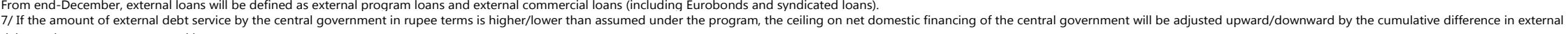
debt service payments measured in rupees.

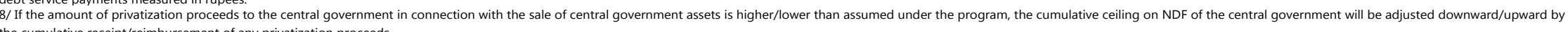
the cumulative receipt/reimbursement of any privatization proceeds.

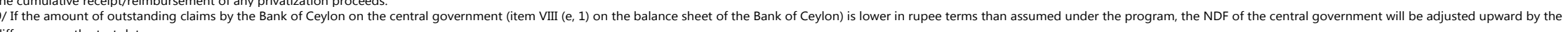
difference on the test date.

argets on NDF include restructuring bonds amounting to Rs. 60,000 million issued to settle outstanding dues from state owned institutions to the Ceylon Petroleum Corporation.

11/ Slight revisions to end-December 2010 and end-December 2011 data are based on unaudited results.

\section{CInternational Monetary Fund. Not for Redistribution}


Table 2. Sri Lanka: Structural Benchmarks (SB)

Structural Benchmarks
Recapitalization of Seylan Bank through a public share issuance.
A contingency plan for orderly workouts of problem banks and financial institutions

will be developed by the CBSL.

$9 / 30 / 2009$

9/30/2009

Approval by the Monetary Board of a revised Banking Act and other pertinent laws and legislations that: (i) improve the bank resolution framework that more clearly defines the provisions for acquisition, and roles of the conservator and liquidator; and (ii) strengthens the definition of large exposures and related parties to better capture all material risks.

Submission by the tax review commission of an interim report, including on base broadening measures to be incorporated into the 2010 budget.

Approval by Parliament of an interim budget for the first four months of 2010 consistent with program targets.

Develop a plan to address outstanding debts between the CEB, CPC and state-owned banks.

Issuance of prudential regulations and guidelines to credit card companies and payment service providers.

Submission to parliament of the 2010 budget consistent with program targets.

Submission to the parliament of a revised Finance Business Act which includes clarifying the legal authority of the CBSL in enforcing its regulations on all deposit taking finance companies.

Submission by the Presidential Tax Commission of a final report, including specific tax reform measures.

Parliamentary approval of full-year 2010 budget consistent with program targets.

Issuance of regulations to establish a deposit insurance scheme.

Submission to parliament of the 2011 budget consistent with program targets,

including income tax and VAT reform measures.

Cabinet approval of a regulatory framework for private-sector superannuation funds.

Restructure the overdue obligations accumulated up to end-2009 by Ceylon

Electricity Board to Ceylon Petroleum Corporation.

Amend $\mathrm{BOI}$ regulations.

Amend the Strategic Investment Law and issue supporting regulations on defining and contracting strategic projects.

Cabinet approval of amendments to the Banking Act.

Cabinet approval of amendments to the Petroleum Act.

Submission to parliament of the 2012 budget.

9/30/2009
$10 / 15 / 2009$

$12 / 15 / 2009$

$12 / 31 / 2009$

$12 / 31 / 2009$

$4 / 30 / 2010$

$5 / 31 / 2010$

$8 / 31 / 2010$

$8 / 31 / 2010$

$9 / 30 / 2010$

$11 / 30 / 2010$

$12 / 31 / 2010$

$12 / 31 / 2010$

$3 / 31 / 2011$

$3 / 31 / 2011$

$3 / 31 / 2011$

9/30/2011

$11 / 30 / 2011$
Implemented

Status

Implemented

Implemented

Implemented with delays

Implemented

Implemented

Implemented

Implemented with delays

Implemented with delays

Implemented with delays

Implemented

Implemented

Implemented

Not met

Implemented with delays

Implemented

Implemented

Implemented with delays

Implemented with delays

Implemented

\section{(CInternational Monetary Fund. Not for Redistribution}




\section{ATTACHMENT II \\ TeChNiCAL Memorandum OF Understanding}

\section{This Technical Memorandum of Understanding sets out a framework for} monitoring the performance of Sri Lanka under the program supported by the StandBy Arrangement (SBA). It specifies the performance criteria and indicative targets (including adjustors) under which Sri Lanka's performance will be assessed for the eighth and final review contemplated for completion by July 20, 2012.

\section{Fiscal TARgets}

\section{A. Indicative Target on Net Domestic Financing of the Central Government}

2. Net domestic financing (NDF) is defined as the change in net credit to the central government by the domestic banking system and the net change in holdings of treasury bills and other government securities by the domestic non-bank sector. For the purpose of program monitoring, the central government is defined to include line ministries, departments, and other public institutions. The Central Bank of Sri Lanka (CBSL), stateowned enterprise, parastatals and other agencies that do not receive subventions from the central government are excluded from the definition of central government. NDF of the central government is defined as the sum of (i) net borrowing from the CBSL (ways and means advances, loans, holdings of treasury bills, treasury bonds, and other central government bonds minus deposits); (ii) net borrowing from domestic commercial banks and the domestic non-bank sector (loans, advances, holdings of restructuring bonds, and holdings of treasury bills and other central government securities minus deposits); and foreign holdings of Treasury Bills and Treasury Bonds. In 2009, NDF of the central government defined in this manner amounted to Rs. 392.5 billion. Of this amount, Rs. 49.0 billion was net borrowing from the domestic banking system, Rs. 185.2 billion was net borrowing from the domestic non-bank sector, Rs. 146.9 billion was net foreign inflows into the Treasury Bill and Treasury Bond markets and Rs. 11.3 billion was net borrowing from other sources.

\section{B. Indicative Target on the Sum of the Overall Balance of the Ceylon Electricity Board and the Ceylon Petroleum Corporation}

3. The balance of the overall profit or loss position of the Ceylon Electricity Board (CEB) and the Ceylon Petroleum Corporation (CPC) from their operating income statements is measured from above the line on an accrual basis. At end-December 2009, the sum of that overall position of the CEB and CPC defined in this manner stood at Rs. -19.4 billion. 


\section{MONETARY TARgeTS}

\section{A. Indicative Target on Reserve Money of the CBSL}

4. Reserve money of the CBSL consists of currency in circulation (with banks and with the rest of the public), financial institutions' domestic currency deposits at the CBSL, and the deposits of following government agencies: the National Defense Fund (General Ledger Acc. No. 4278), the Buddha Sasana Fund A/C (General Ledger Acc. No. 4279); and the Road Maintenance Trust Fund (General Ledger Acc. No. 4281). At end-December 2009, reserve money defined in this manner stood at Rs. 303.5 billion. For the purpose of program monitoring, reserve money on the test date shall be measured as average reserve money during the prevailing reserve week (Friday to Thursday).

\section{EXTERNAL SECTOR TARGETS}

\section{A. Performance Criterion on Net Official International Reserves}

\section{Net official international reserves (NIR) is defined as (i) the difference between} the gross foreign assets and liabilities of the CBSL and (ii) the balance of State Treasury's (DSTs) Special Dollar and Yen Revolving accounts, both expressed in terms of market values. Gross foreign assets of the CBSL consists of monetary gold; foreign exchange balances held outside Sri Lanka; foreign securities (valued in market prices); foreign bills purchased and discounted; the reserve position at the IMF and SDR holdings; and the Crown Agent's credit balance. Excluded from gross foreign assets will be participation in international financial institutions; holdings of nonconvertible currencies; holdings of precious metals other than monetary gold; claims on residents (e.g., statutory reserves on foreign currency deposits of commercial banks and central bank foreign currency deposits with resident commercial banks) pledged, non-liquid, collateralized or otherwise encumbered foreign assets (such as the government's war risk insurance deposit with Lloyds during 2001/02); and claims in foreign exchange arising from derivative transactions (such as futures, forwards, swaps and options). Gross foreign liabilities are all foreign currency denominated liabilities of the CBSL to non-residents; the use of Fund credit; Asian Clearing Union debit balance and commitments to sell foreign exchange arising from derivatives such as futures, forwards, swaps, and options. In addition, NIR will include the balance of the DSTs' Special Dollar and Yen Revolving accounts. DST accounts are foreign currency accounts held by the Treasury and managed by the CBSL as an agent of the government. At end-December 2009, NIR defined in this manner stood at U.S. dollars 4,150 million.

\section{The following adjustment will apply:}

6. If the amount of commercial borrowing (including Eurobonds and syndicated loans) - as set out in Table 4-is higher/lower in U.S. dollar terms than assumed under the 
program, the floor on NIR will be adjusted upward/downward by the cumulative difference on the test date.

7. An adjustor to the NIR target of the CBSL will be implemented to reflect changes in the CBSL's net position under foreign exchange forwards and swaps. Specifically, if the outstanding value on forwards and swaps is higher/lower than assumed under the program (Table 4), the NIR target of the CBSL will be adjusted upward/downward by the change in the outstanding value of forwards and swaps relative to the programmed level. The CBSL's outstanding value on swaps and forwards was $\$ 782$ million at February 29, 2012. The downward adjustment in the NIR target will be up to a maximum of $\$ 600$ million.

8. The floor on NIR will be adjusted upward for any increase in Sri Lanka's allocation of Special Drawing Rights (SDR) from the IMF. Sri Lanka's SDR allocation at the time of approval of this arrangement amounted to SDR 70.868 million.

\section{B. Performance Criterion on External Payment Arrears}

9. A continuous performance criterion applies to the nonaccumulation of external payments arrears on external debt contracted or guaranteed by the central government (as defined in 92) or the CBSL. External payments arrears consist of external debt-service obligations (principal and interest) on debt as defined in 99 that have not been paid at the time they are due, as specified in the contractual agreements. However, overdue debt and debt service obligations that are in dispute will not be considered as external payments arrears for the purposes of program monitoring.

\section{DATA REporting ReQuirements}

10. Sri Lanka shall provide the Fund, through reports at intervals or dates requested by the Fund, with such information as the Fund requests in connection with the progress of Sri Lanka in achieving the objectives and policies set forth in the Memorandum of Economic and Financial Policies. All the program monitoring data will be provided by the Ministry of Finance and the Central Bank of Sri Lanka (CBSL). Data relating to the external and monetary targets will be furnished within no more than three weeks after the end of each month. ${ }^{1}$ With regards to the fiscal targets, the data in table 5 will be furnished within no more than five weeks after the end of each month and the data in table 6 within no more than nine weeks after the end of each month. For the overall balance of the CEB and the CPC, estimates will be available within four weeks.

\footnotetext{
${ }^{1}$ The deadline for submitting monetary and external data for end-December 2010 and 2011 will be five weeks due to the added time needed to close the books at the end of the year.
} 
11. For the purpose of monitoring the fiscal performance under the program, data will be provided in the format as shown in Tables 5 and 6.

12. For the purpose of monitoring the monetary targets under the program, data will be provided in the format shown in Table 7.

13. For the purpose of monitoring the external sector performance under the program, data will be provided in the format shown in Tables 8 and 9 . 
Table 1. Sri Lanka: External Financing Assumptions (cumulative from the beginning of the year, in millions of rupees)

\begin{tabular}{lrrrrrrrr}
\hline & 2010 & & 2011 & & \multicolumn{2}{c}{2012} \\
& Dec & & Mar & Jun & Dec & & Mar & Jun \\
\cline { 2 - 5 } \cline { 5 - 7 } External Program Loans & 5,699 & $\ldots$ & $\ldots$ & $\ldots$ & & $\ldots$ & $\ldots$ \\
External Commercial Loans & 0 & 0 & 0 & 0 & & $\ldots$ & $\ldots$ \\
External Debt Service & 96,555 & 31,221 & 57,915 & 116,466 & & $\ldots$ & $\ldots$ \\
\hline
\end{tabular}

Table 2. Sri Lanka: Assumptions on Privatization Proceeds (cumulative from the beginning of the year, in millions of rupees)

\begin{tabular}{|c|c|c|c|c|c|c|}
\hline & \multirow{2}{*}{$\begin{array}{r}2010 \\
\text { Dec }\end{array}$} & \multicolumn{3}{|c|}{2011} & \multicolumn{2}{|c|}{2012} \\
\hline & & Mar & Jun & Dec & Mar & Jun \\
\hline Privatization Proceeds & 0 & 0 & 0 & 0 & $\ldots$ & $\ldots$ \\
\hline
\end{tabular}

Table 3. Sri Lanka: Outstanding Claims by the Bank of Ceylon on the Central Government (item VIII $(e, 1)$ on the balance sheet of the Bank of Ceylon, in millions of rupees)

\begin{tabular}{|c|c|c|c|c|c|c|}
\hline & \multirow{2}{*}{$\begin{array}{r}2010 \\
\text { Dec }\end{array}$} & \multicolumn{3}{|c|}{2011} & \multicolumn{2}{|c|}{2012} \\
\hline & & Mar & Jun & Dec & Mar & Jun \\
\hline Foreign Bills Inward & 6,038 & 1,575 & 1,575 & 1,575 & $\ldots$ & $\ldots$ \\
\hline
\end{tabular}

Table 4. Sri Lanka: External Financing for NIR Purposes

(cumulative from the beginning of the year unless otherwise stated, in millions of U.S. dollars)

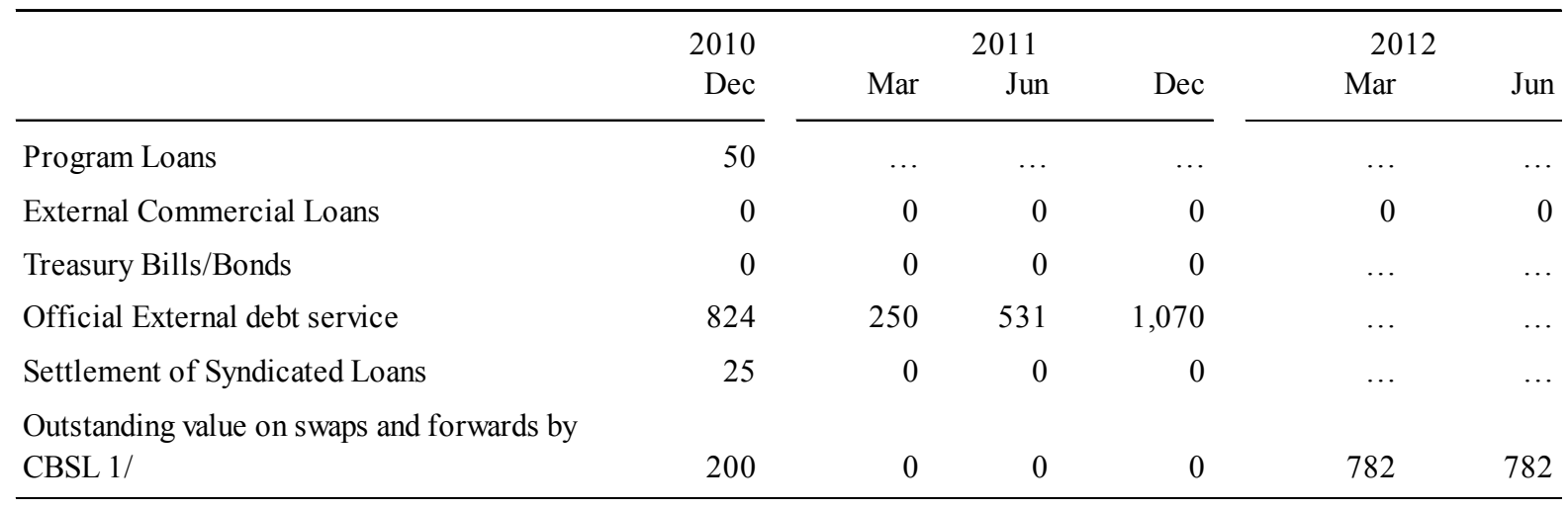

1/ End of period stock. 
Table 5. Sri Lanka: Summary of Central Government Operations 1/

(In millions of rupees)

\section{Total revenue}

Tax revenue

Income taxes

Value added tax

Domestic

Imports

Excise taxes

Tax on liquor

Tax on cigarettes/tobacco

Petroleum

Motor vehicle

Other

Stamp duties

Port and airport development duty

Debit tax

Import duties

Cess levy

Special commodity levy

Nation Building Tax

Telephone subscriber levy

Licence taxes and other

\section{Nontax revenue}

\section{Grants}

Total expenditure and net lending

of which: Interest payments

$$
\begin{aligned}
& \text { Foreign } \\
& \text { Commercial } \\
& \text { Domestic }
\end{aligned}
$$

\section{Overall balance of central Government}

\section{Financing}

Net domestic financing

Net external financing

of which: Program loans

of which: Project loans

of which: Commercial borrowing

of which: Amortization

Privatization

1/ As agreed for the purpose of monitoring the program 
Table 6. Sri Lanka: Central Government Expenditure 1/

(In millions of rupees)

Total expenditure and net lending

\section{Current expenditure}

Civil service wages and salaries

Other civilian goods and services

Security related expenditure

Subsidies and transfers

Households

Of which: Samurdhi

\section{Pensions}

Fertilizer

Institutions, corporations, other government agencies

Interest payments

Foreign

Commercial

Domestic

\section{Capital expenditure and net lending}

$1 /$ As agreed for the purpose of monitoring the program

Table 7. Sri Lanka: Balance Sheet of the Central Bank 1/

(In millions of rupees)

\section{Net foreign assets}

Foreign assets

Cash and balances abroad

Foreign securities

Claims on ACU

SDRs

IMF related assets

Receivables

Foreign currency reserve

\section{Foreign liabilities}

IMF and nonresident account

Liabilities to ACU

Net domestic assets

Claims on government

Advances

Treasury bills and bonds

Cash items in collection

\section{Government deposits}

\section{Claims on commercial banks}

Medium and long term

Short term

\section{Other items net}

Reserve money

Currency in circulation

Commercial bank deposits

Government agencies deposits

$1 /$ As agreed for the purpose of monitoring the program 
Table 8. Sri Lanka: Summary of Central Bank Foreign Exchange Operations 1/

(In millions of USD)

\section{Total inflows}

Loans

Program

IMF

Project (cash component only)

Interest earnings, forex trading profits, cap gains

Purchases of foreign exchange

Change in balances in DST's A/Cs

Other inflows

Borrowing from SLDBs

Loans from FCBUs

Syndicated Loans

Commercial loans

Repayments of BOC and PB claims

\section{Total outflows}

Public Debt Service Payments

Amortization

Principal (foreign loans)

Settlement SLDBs

Settlement FCBU

Settlement of syndicated loans

Interest

Foreign loans

Domestic foreign currency loans

Payments to the IMF/ change in valuation of liabilities

Foreign exchange sales to commercial banks

Foreign exchange deposits at $\mathrm{BOC}$ and PB

\section{Net flow at current rates (1-2)}

\section{Net International Reserves}

Gross International Reserves

Cumulative net inflows into the Treasury Bill/Bond market

$1 /$ As agreed for the purpose of monitoring the program 
Table 9. Sri Lanka: Estimated Gross Official Reserve Position (in US\$ million) $1 /$

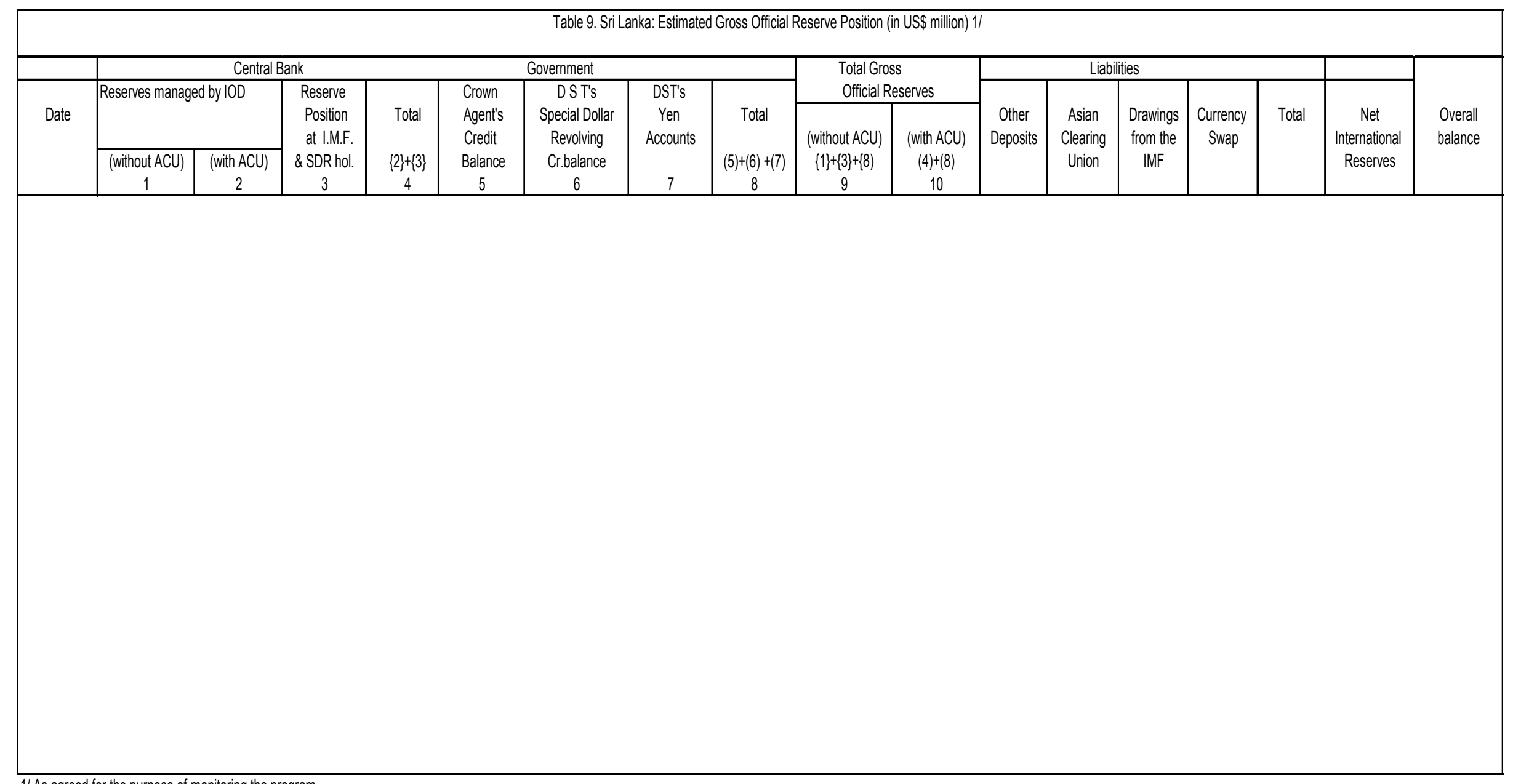




\section{IMF Executive Board Completes Eighth and Final Review Under the Stand-By Arrangement for Sri Lanka and Approves US\$ 415.0 Million Disbursement}

The Executive Board of the International Monetary Fund (IMF) today completed the eighth and final review of Sri Lanka's economic performance under a program supported by a Stand-By Arrangement (SBA). The completion of the review enables the immediate disbursement of an amount equivalent to SDR 275.6 million (about US\$ 415.0 million), bringing total disbursements under the arrangement to an amount equivalent to SDR 1.6536 billion (about US\$ 2.49 billion).

The SBA was approved on July 24, 2009 (see Press Release No. 09/266) for an amount equivalent to 400 percent of Sri Lanka's quota.

Following the Executive Board's discussion on Sri Lanka, Mr. Naoyuki Shinohara, Deputy Managing Director and Acting Chair, stated:

"Following robust growth in the first quarter of 2012, activity has started moderating in response to policy tightening and weakening global demand. Headline inflation has increased, but core inflation remains relatively stable, while tighter monetary and credit policies have begun slowing credit and import growth. The external current account deficit is narrowing, and international reserves have stabilized.

"The current monetary policy stance is appropriate, and monetary conditions should remain firm in the near term given high headline inflation and possible second-round effects. With a flexible exchange rate regime, monetary policy can increasingly focus on inflation control to achieve broader macroeconomic stability while allowing the exchange rate to act as a buffer for external shocks. Foreign exchange market intervention should thus be limited to smoothing excessive volatility, and steps should be taken to gradually deepen the foreign exchange market.

"The slowdown in economic activity and declining imports are adversely affecting fiscal revenues, while interest payments on government debt are higher than budgeted. The 
authorities are committed to meeting their 2012 deficit target by restraining expenditure, but a redoubling of effort to strengthen revenue administration is needed. Furthermore, continued structural reforms are required to put state-owned energy enterprises on a sound financial footing.

"The ongoing FSAP update is assessing potential vulnerabilities in the financial sector. The authorities should remain vigilant for systemic risks, and recommendations in the update can be used to strengthen the financial system further.

"The Sri Lankan authorities have undertaken substantial macroeconomic policy adjustments to stabilize reserves. It will be important to continue macroeconomic stabilization and structural reforms efforts, in particular maintaining exchange rate flexibility while building international reserves, given the uncertain global outlook. A successor arrangement with the Fund would provide valuable support to the authorities in these endeavors." 


\section{Statement by P. Nandalal Weerasinghe, Alternate Executive Director for Sri Lanka July 20, 2012}

\section{Overall Performance under the SBA}

1. When Sri Lanka was facing balance of payments difficulties towards the latter part of 2008 and early 2009 due to large capital outflows triggered by the collapse of Lehman Brothers, the authorities commenced negotiating a SBA with the Fund in February 2009. The main objectives of the SBA were (1) fiscal adjustment to reduce the central government budget deficit and bring the two major SOEs to breakeven, (2) continued flexibility in the exchange rate while building up external reserves and (3) measures to preserve the soundness of the financial sector. By the time the SBA was approved by the Board in July 2009, the authorities had already implemented necessary measures to reverse the declining trend in external reserves and initiated reforms to strengthen fiscal consolidation. The approval of the SBA enhanced investor confidence which had already been boosted by the end of three decade long conflict.

2. The success of the SBA is clearly evident as all economic fundamentals have improved significantly compared to early 2009. During the last three years, the economy has been growing at around 8 per cent; external reserves have increased from as low as US\$ 1.2 billion in early 2009 to more than US\$ 6 billion by end June 2012. The fiscal deficit has come down from almost 10 per cent of GDP in 2009 to below 7 per cent by 2011; inflation has been maintained within single digits throughout the period compared to double digit inflation that prevailed for a long period prior to 2009. During the program period, Sri Lanka has improved sovereign ratings and has enhanced access to international capital markets by issuing several Euro bonds with longer maturities while tightening spreads continuously. During the program period, Sri Lanka was also graduated from a PRGT eligible country to middle income status as per capita income rose and exceeded the US\$2000 level by 2008 from around US\$ 1000 level in 2004.

3. The completion of the SBA marks the longest engagement Sri Lanka has had with the Fund and the single largest facility Sri Lanka has ever obtained from a multilateral institution. The successful completion has also proved the authorities' track record of maintaining economic discipline. The authorities greatly appreciate the support and continuous engagement extended by staff, management and the Board throughout the program.

\section{Performance under the Eighth Review}

4. The Seventh Review under the SBA was completed in April 2012 following the implementation of a decisive policy package by the authorities during the first quarter of 2012. The package was aimed at addressing external sector stresses due to the unprecedented growth in imports fueled by high growth in private sector credit as a result of the boom in consumption and investment demand, generated by the post-conflict optimism and increased investment opportunities. The reform package has already begun to deliver promising results in terms of strengthening external reserves, declining trade 
and current account deficits and slowing down growth in private sector credit. Despite slower than expected revenue collection due to lower imports and higher interest expenditure, the government is likely to meet the fiscal deficit target for the first half through expenditure controls and is strongly committed to meet the annual targets announced in Budget-2012. Adjustments to petroleum prices and electricity tariffs together with easing oil prices in international markets have improved the financial positions of the state owned Ceylon Petroleum Corporation (CPC) and Ceylon Electricity Board (CEB).

\section{Program Performance}

5. Performance Criterion for net international reserves (NIR) for end June has been met despite higher than expected settlement of petroleum bills during the second quarter due to reduction of oil imports from Iran on credit basis. The indicative target for reserve money for end June has been met. Available preliminary data suggest that the indicative target for net domestic financing (NDF) has also been met. All structural benchmarks except for reform of the regulatory framework for private pension funds have been implemented. On the basis of the successful achievement of program objectives set out under the SBA, the authorities request approval of the completion of the Eighth and final review.

\section{Recent Economic Developments and Outlook}

6. After two consecutive years of growth above 8 per cent, the Sri Lankan economy has grown by 7.9 per cent during the first quarter of 2012. Growth is expected to further slowdown during the balance period of 2012 due to recent demand management policies implemented by the authorities together with the adverse impact on the Agricultural sector due to drought conditions. The global economic situation has also posed some downside risk as the US and Euro areas are the major markets for Sri Lankan exports. The economy is therefore, projected to grow by around 7 per cent during 2012 supported mainly by the continued momentum in post conflict reconstruction, major externally funded public investment programs and private sector investment activities. The authorities are confident that policies implemented so far strike the right balance between curtailing the current account deficit and maintaining a sustainable growth in the medium term.

\section{Monetary and Exchange Rate Policy}

7. Both headline and core inflation have remained within the central bank's targeted range of around mid single digit levels since 2009 until around the first quarter of 2012 due to the prudent implementation of monetary policy by the Central Bank and improved domestic supply conditions. In order to curtail the rising demand for credit and monetary expansion, and thereby possible demand driven pressures on inflation, the Central Bank has commenced a gradual monetary tightening process by raising the statutory reserve requirement in April 2011 followed by increasing policy rates in February and April 2012, along with a ceiling imposed on banks on maximum credit growth. In response, 
market interest rates have shifted upward more than the increases in policy rates and credit growth has been decelerating during recent months.

8. Further, headline inflation on year-on-year basis has increased to 9.3 per cent by end June from 2.7 per cent at end February. The impact of higher domestic petroleum, electricity and transport prices, and the depreciation of the rupee has caused a spike in year-on-year inflation. The authorities expect that the current monetary policy stance would be appropriate to stabilize inflation and they stand ready to take appropriate action if inflation remains at an elevated level in the coming months.

9. Greater flexibility in the exchange rate has served to stabilize external reserves, and has also curtailed trade and current account deficits, compared to the second half of 2011. The authorities have demonstrated their commitment to greater exchange rate flexibility by allowing the rupee to depreciate by around 14 per cent during the first half of 2012. The decline in official reserves has been arrested and turned around despite the early settlement of petroleum bills of a high value due to lower imports of petroleum from Iran. The authorities feel that higher inflows of FDI and portfolio investments together with the issuance of the fifth international sovereign bond would lead to a significant surplus in the BOP compared to the deficit in 2011, strengthening the external reserve position further during 2012.

\section{Fiscal Policy and State Enterprise Reforms}

10. The authorities have been pursuing two key fiscal objectives under the program: (a) to bring down the fiscal deficit and public debt to a sustainable level by implementing necessary tax reforms and prudent public expenditure management, and (b) to improve the financial position of SOEs. They have made significant progress towards achieving both objectives. The fiscal deficit as a percentage of GDP has been on a steady declining path since 2010. The government has already expressed its strong commitment in the Budget 2012 to reduce the budget deficit further to 6.2 per cent of GDP in 2012. The authorities have already demonstrated their ability to meet fiscal targets for 2012 by meeting the end-June indicative target for NDF and implementing almost all structural benchmarks under the SBA. However, revenue collection during the first half has been lower than expected mainly due to lower revenue from import related taxes. The authorities have however been able to maintain the budget deficit in line with expectations through better expenditure management while maintaining capital expenditure to around 6 per cent of GDP, as envisaged.

11. With regard to reforming the major SOEs, petroleum prices and the electricity tariff have been revised several times and brought to the levels that reflect cost of inputs. In addition, some outstanding dues between CPC and CEB have been settled by issuing bonds. Several regulatory and governance reforms have also been introduced in both corporations. New investments are being made to increase the share of low cost power generation in the medium term so that both SOEs would be placed on a sustainable financial footing while maintaining energy prices at competitive rates. 


\section{Financial Sector Developments}

12. The financial sector remains healthy with prudential indicators reflecting adequate capital and liquidity buffers and healthy profit levels. The Capital Adequacy Ratio of the banking sector has been maintained at 14.9 per cent at end March 2012 and profitability indicators remain healthy. NPL ratios have increased marginally to 4 per cent by end March from 3.8 per cent at end 2011 reflecting the impact of the sharp rise in interest rates. The resilience of the financial sector is evident by the fact that the recent interest rate and exchange rate adjustments are not likely to cause material impact on prudential indicators of the financial sector.

\section{Conclusion}

13. The authorities value the contribution made by the Fund towards the progress of the Sri Lankan economy since 2009, under the SBA. Upon the successful completion of the SBA, the authorities look forward to continued close engagement with the Fund and intend to discuss the possibility of financial support for their economic development agenda under an Extended Fund Facility, preferably with a budget support component, as financing the budget deficit at a reasonable cost to support further reforms in SOEs, revenue administration and public financial management would be more relevant than a pure balance of payments support at this juncture. 